\title{
EXPEDICIONES A LAS COSTAS DE LA PATAGONIA OCCIDENTAL EN EL PERÍODO COLONIAL
}

\section{XIMENA URBINA C.*}

\begin{abstract}
RESUMEN
Este artículo, que tiene como tema de estudio un espacio geográfico, pretende aportar a la discusión sobre el cómo los territorios van adquiriendo significados para Occidente en el período colonial. Es una contribución para la comprensión del proceso de tránsito de la costa patagónica pacífica, desde un área intermedia entre Chiloé y el estrecho de Magallanes; luego una zona perteneciente a Chiloé, en el cual la provincia se proyectaba por medio de expediciones marítimas, pero que no incorporaba ni permanecía en él; a finalmente un territorio con singularidad histórica propia. Se presentará una propuesta de etapas o periodización de los viajes y exploraciones coloniales en la costa patagónica, y las motivaciones que hubo detrás de ellas, para comprender el proceso de proyección hacia esos territorios y el sentido que sus contemporáneos les dieron.
\end{abstract}

PALABRAS CLAVE: expediciones, historia, Patagonia, colonial.

\section{EXPEDITION TO THE COASTS OF WESTERN PATAGONIA IN THE COLONIAL PERIOD}

\begin{abstract}
This article, which has a territory as its subject of study, aims to contribute to the discussion on how territories acquired a new meaning for the West during the colonial period. It is a contribution to the understanding of the transition process of the south pacific Patagonian coast, from an intermediate area between Chiloe and the Magellan Strait, to a territory belonging to Chiloe, in which the province was expanded through maritime expeditions, but did not incorporate or maintain it, to finally a territory with its own historical singularity. In order to shed light about the process of expansion to these territories and the meaning that their contemporaries gave them, this paper will present a proposal of stages or periods of the colonial explorations on the Patagonian coast, as well as the motivations that were behind them.
\end{abstract}

KEY WORDS: expeditions, history, Patagonia, colonial.

\footnotetext{
*Pontificia Universidad Católica de Valparaíso, Instituto de Historia. Paseo Valle 396, Viña del Mar, Chile. maria.urbina@ucv.cl.
} 


\section{INTRODUCCIÓN}

La extensa y desmembrada costa patagónica entre el archipiélago de Chiloé, por el norte, y el estrecho de Magallanes, por el sur, entre los aproximadamente 43 y 56 grados de latitud sur, es un territorio que actualmente pertenece a las regiones de Aysén, y a la de Magallanes y Antártica Chilena ${ }^{1}$. Esas regiones político-administrativas, las dos más australes de Chile, están conformadas por dos paisajes muy disímiles: uno bordemarino e insular, y otro continental y pampeano, el que se prolonga hasta el océano Atlántico. En ellos se pueden advertir distintas identidades ${ }^{2}$, como diferente es su geografía y su poblamiento. La Patagonia, en su vertiente del Pacífico, es un territorio de impronta marítima históricamente conectado con el archipiélago de Chiloé, con quien comparte un pasado común ${ }^{3}$. Hacia el interior de fiordos y golfos, al oriente de los Andes, el paisaje cambia a tierras llanas, donde se pierde la vista en el horizonte, y azota el viento en un paisaje estepárico: es un territorio de impronta continental cuyos amplios espacios han estado históricamente conectados con el área del lago Nahuelhuapi y las llanuras que terminan en el océano Atlántico y el estrecho de Magallanes.

Como ha señalado Isidoro Vázquez de Acuña, las tierras al sur de Chiloé, tanto las costas del mar como el interior del continente, y hasta el confín austral, durante el período colonial pertenecieron jurídicamente a la provincia de Chiloé, con capital en Santiago de Castro, desde que fuera fundada en $1567^{4}$. Los gobernadores insulares se referían a esta

1 Este artículo es fruto del Proyecto Fondecyt Regular 20122013, N ${ }^{\circ}$ 1120704, "La Patagonia Insular en el período colonial: exploraciones, interacción europeo-indígena, imagen y ocupación del territorio", del que soy Investigadora Titular.

2 Osorio, M. (2007). Aysén, matices de una identidad que asoma. En: M. Osorio, G. Saavedra y H. Velásquez (2007). Otras narrativas en Patagonia. Tres miradas antropológicas a la región de Aysén (pp. 9-33). Coyhaique: Ediciones Ñirre Negro.

3 Saavedra, G. (2007). Desarrollo endógeno y dinámicas de significación cultural en el borde costero del sur austral chileno. En M. Osorio, G. Saavedra y H. Velásquez (2007), pp. 35-65.

4 Vázquez de Acuña, I. (1993). La jurisdicción de Chiloé (siglos XVI al XX). Su extensión, exploración y dominio. Boletín de la Academia Chilena de la Historia, 103, 111-191. jurisdicción que les pertenecía, como se lee en una certificación dada en Castro, a 5 de agosto de 1715, por el maestre de campo general, Pedro de Molina Vasconcelos, gobernador desta provincia de Chiloé y lugarteniente de capitán general de mar y tierra hasta las costas del Estrecho, etc. ${ }^{5}$. Mateo Martinic argumenta, a su vez, sobre la autoridad colonial de Chiloé en Patagonia y da, entre otros ejemplos, a fray Antonio Vásquez de Espinoza [ca. 1630] $]^{6}$. Las costas australes fueron consideradas como parte de esa provincia, porque aquellos archipiélagos se veían como una prolongación del de Chiloé, y también en ellos se imponía la navegación como forma de apropiación del territorio. La presencia, eso sí, fue más nominal que real, porque no hubo asentamiento permanente de españoles en aquel inmenso territorio, excepto el corto tiempo que se mantuvieron las colonias del estrecho de Magallanes, fundadas por Pedro Sarmiento de Gamboa en 1584, y los dieciocho meses en que se mantuvo en pie y con dotación, el fuerte de Tenquehuén levantado en la península de Taitao, en 1750, a los casi 47 grados de latitud sur. Con la frustración del plan poblador del Estrecho, la ocupación efectiva de esas tierras dio paso a una modalidad de proyección y vigilancia que correspondió a Chiloé. Era asunto de la mayor importancia, por cuanto las costas occidentales estuvieron desde fines del siglo XVI amenazadas por navegantes enemigos de la corona de España.

5 Silva y Molina, A. [1899], Historia de la provincia de Chiloé bajo la dominación española (manuscrito) en ANH, FV, Vol. 141, f. 35. Otro ejemplo: Rodolfo Urbina dice que al gobernador de la Provincia le competía la vigilancia de toda la costa austral hasta salir al Atlántico a través del estrecho de Magallanes. Urbina, R. (1998). Gobierno y sociedad en Chiloé colonial. Valparaíso: Editorial Puntángeles, p. 42.

6 Dice Vásquez de Espinoza que el reino de Chile estaba conquistado y poblado desde el valle de Copiapó referido, hasta la ciudad de Osorno, en 40 grados y 26 minutos, y hasta el archipiélago de Chiloé, donde está la ciudad de Castro en 43 grados, y lo restante hasta el Estrecho, que es la costa de Los Césares, donde hay algunas naciones bárbaras y de costumbres salvajinas, y la tierra adentro habitada de la nación de los patagones gigantes vestidos de pieles de venados, y otras naciones, están todas por conquistar, así por la aspereza de las sierras y cordilleras nevadas, como por ser de poco fruto y haber en aquellas regiones muchos despoblados, por la altura y frialdad de la región. Vásquez de Espinoza, Antonio [1619], 1896. Descripción del reino de Chile, Santiago, p. 73, citado por Martinic, M. (1992). Historia de la Región Magallánica. Tomo I. Santiago: Universidad de Magallanes, p. 250. 
Aun más, la conservación de la provincia de Chiloé después del proceso 1598-1602, en que la rebelión mapuche-huilliche obligó a abandonar las ciudades fundadas al sur del río Bío-Bío, con excepción de la isla grande de Chiloé - pero que la dejó como un enclave español en un territorio poblado exclusivamente de indígenas desde el citado Bío-Bío hasta el extremo sur de América -, se explica por vigilar el Estrecho y el amplio espacio intermedio entre él y Chiloé, frente a incursiones extranjeras que pusieran en peligro a Chile central. Esta decisión se vio reforzada en 1600 y 1643, cuando escuadras holandesas atacaron y ocuparon Castro y Valdivia. Por eso, aunque aislada y marginal, se mantuvo la provincia de Chiloé.

De esta forma, en los siglos coloniales, las muy parcialmente conocidas tierras al sur de Chiloé, fueron exploradas desde la provincia insular, lo que no significó una ocupación permanente, pero si una proyección constante. Así lo explicó Walter Hanisch, cuando interpretó a la isla de Chiloé como la capitana de las rutas australes, capitana hacia Aysén de una frontera móvil, posibilitada por la embarcación adecuada a esas costas, que Hanisch retrató en su capítulo Elogio a la piragua ${ }^{7}$. Una de las particularidades de esta proyección o frontera móvil fue que, a diferencia de las expediciones en el extremo opuesto del continente, es decir, el norte de la Nueva España, las exploraciones al sur de Chiloé tenían un límite sur, que era el estrecho de Magallanes, zona poblada de indígenas, y conocido desde 1520, antes de la conquista de Chile- aunque no se descartaba la presencia de tierra emergida al sur de dicho Estrecho-, lo que hacía al área más austral de la gobernación de Chile un espacio intermedio. Era de difícil acceso, por la geografía de islas, canales y bajíos, pero también por el clima frío, ventoso y lluvioso, y porque el océano Pacífico golpea fuertemente al litoral en esas latitudes, dificultando mucho la navegación cercana a la costa. Se consideraba, además de lejano y peligroso, un territorio carente de los atractivos económicos que en la mayor parte de América habían movilizado rápidamente a los conquistadores a través de la ocupación del territorio a base de la fundación de ciudades y repartimientos de tierras $e$ indios, que se concentró entre México central y la zona del río Maule en Chile; atractivos como el

\footnotetext{
Hanisch, W. (1982). La isla de Chiloé, capitana de rutas australes. Santiago: Academia Superior de Ciencias Pedagógicas de Santiago, pp. 23-25.
}

oro, plata y piedras preciosas, tierras aptas para la agricultura y ganadería, e indígenas agricultores y numerosos. Al contrario, las descripciones de los marinos españoles Ulloa y Ladrillero, en la década del 50 del siglo XVI, habían retratado la enorme diferencia cultural entre los habitantes de esas latitudes y los españoles. Pero era un territorio poco atractivo, además, porque su condición de insularidad imponía movilizarse exclusivamente en embarcaciones, lo que era precisamente la antítesis del modo de vida español, centrado en la agricultura como manera de establecerse en un territorio, y en el caballo como medio para transitarlo.

La costa patagónica occidental ha recibido reiterada atención de la historiografía. Desde poco mas de tres décadas casi en forma contemporánea cuatro investigadores abordaron este territorio bordemarino desde ópticas parecidas. Rodolfo Urbina, en su tesis doctoral de 1980 sobre Chiloé, publicada como libro en 1983, estudió en un apartado de su capítulo primero, el Territorio Austral, trazando una semblanza del significado de esta frontera sur en el período colonial: tierra poblada de etnias consideradas muy disímiles con los españoles, dificultad de acceso, y vigilancia desde Chiloé en caso de guerra con Inglaterra ${ }^{8}$. Casi al mismo tiempo, Walter Hanisch estaba escribiendo otro libro sobre Chiloé, precisamente sobre sus fronteras, y abordó en un capítulo los Caminos australes a los Chonos, a Guayaneco y aun mas allá ${ }^{9}$, en el que hizo un recuento exhaustivo de las expediciones australes, relevando documentación hasta entonces no citada, de la Sala Medina de la Biblioteca Nacional, y de distintos fondos del Archivo Nacional, ambos de Santiago. Por su parte, Mateo Martinic en su Historia de la Región Magallánica, del año 1992, que aumentó en su libro sobre Aysén, del 2005, ha proporcionado una fundamentada explicación del arribo y la presencia de los foráneos en el territorio en cuestión, desde Fernando de Magallanes hasta la colonización del siglo XX, con valiosas referencias geográficas y cartográficas del período que aquí nos interesa ${ }^{10}$. Además su Archipiélago Patagónico.

8 Urbina, R. [1983] (2012). La periferia meridional indiana. Chiloé en el siglo XVIII. Valparaíso: Ediciones de la Pontificia Universidad Católica de Valparaíso, pp. 35-39.

9 Hanisch, W. (1982), pp. 41-89.

10 Martinic, M. (1992) y (2005). De la Trapananda al Áysen. Santiago: Pehuén Editores, pp. 49-69. 
La última frontera ${ }^{11}$, por el tratamiento que da del territorio, de las relaciones con las etnias originarias con él, y por las imágenes o interpretaciones que de ese archipiélago se fueron construyendo, ha sido muy importante para la comprensión del territorio patagónico insular como un ámbito cultural. Por último, en los años noventa, Isidoro Vázquez de Acuña publicó varios artículos sobre expediciones coloniales a las costas australes de Chiloé, trabajo que luego se condensó en su Historia naval del Reino de Chile ${ }^{12}$. Desde la antropología, las expediciones como fuente etnográfica han generado pocos pero notables trabajos ${ }^{13}$.

En cuanto a la historia de la costa patagónica occidental en el siglo XIX, las fuentes son fruto de las expediciones geográficas de la armada británica en la primera mitad de ese siglo ${ }^{14}$, las expediciones marítimas de reconocimiento del territorio chileno, en la segunda mitad del siglo, realizadas por la Armada de Chile ${ }^{15}$, y en las internaciones en ríos y valles de fines de ese siglo, a propósito de la discusión sobre los límites entre Chile y Argentina ${ }^{16}$. Ambos intereses generaron las

11 Martinic, M. (2004). Archipiélago Patagónico. La última frontera. Punta Arenas: Ediciones de la Universidad de Magallanes.

12 Vázquez de Acuña, I. (2004). Historia naval del Reino de Chile. Valparaíso: Compañía Sudamericana de Vapores.

13 Quiroz, D. (1985). La expedición del piloto Juan García Tao a la Patagonia Occidental Insular (1620-1621). Boletín del Museo Mapuche de Cañete, 1, 56-61. Quiroz, D., Olivares, J. (1988). Nómades canoeros de la Patagonia septentrional Insular: el mundo de don Pedro del Agua. En O. Silva, E. Medina y E. Téllez (Eds.), Encuentro de etnohistoriadores (pp. 10-33). Santiago: Departamento de Ciencias Históricas, Universidad de Chile. Álvarez, R. (2002). Reflexiones en torno a las identidades de las poblaciones canoeras situadas entre los $44^{\circ}$ y $48^{\circ}$ de latitud sur, denominadas 'chonos'. Anales del Instituto de la Patagonia, Serie Ciencias Humanas, 30 , 79-86.

14 Fitz-Roy, R. (1839). Narratives of the surveying voyages of H.M.S. Adventure and Beagle between the years 1826 and1836 Describing their examination of the southern shores of South Americ and the Beagle's circunnavigation of the globe. 3 Vols. Londres: Henry Colbun.

15 Francisco Hudson, 1856-1857, Anuario Hidrográfico de la Marina de Chile, 1884; y Enrique Simpson, 1870-1873, (1874). Exploraciones hechas por la corbeta Chacabuco al mando del capitán de fragata don Enrique M. Simpson en los archipiélagos de Guaitecas, Chonos y Taitao. Santiago: Imprenta Nacional.

16 Ramón Serrano Montaner, 1885-1886, (1886). Reconocimiento del río Buta-Palena y del canal de Fallos por el vapor de la República, "Toro". Anuario Hidrográfico publicaciones de documentos coloniales existentes en archivos en el Anuario Hidrográfico de la Marina de Chile $^{17}$, en la Revista Chilena de Historia y Geografía ${ }^{18}$, además de estudios y libros ${ }^{19}$.

de la Marina de Chile, 9, 72-202, y Hans Steffen, 18921902. Steffen, H. (2010). Viajes de exploración y estudio en la Patagonia Occidental: 1892-1902. 2 vols. Santiago: Dirección de Bibliotecas, Archivos y Museos; Steffen, H. (2009). Patagonia Occidental: las cordilleras patagónicas y sus regiones circundantes. Descripción del terreno basada en exploraciones propias con un bosquejo de la historia de las expediciones practicadas en la región. 2 tomos. Aspillaga, E., Catalán, L. (Eds). Santiago: La Silla

${ }^{17}$ Viaje del capitán Juan Ladrillero al descubrimiento del estrecho de Magallanes (1879), Anuario Hidrográfico de la Marina de Chile, 5, 482-520; Relación del viaje al Estrecho de Magallanes, escrita por Juan Ladrillero (1880), Anuario Hidrográfico de la Marina de Chile, 6, 456-519; Relación del sargento mayor don Bartolomé Gallardo hecha en Lima de orden de V.E. sobre el viaje que hizo en reconocimiento a las poblaciones de los ingleses con todo lo sucedido en él y paraje donde llegó (1674-1675), Anuario Hidrográfico de la Marina de Chile, 14, 525-537; Relación diaria del viaje que se ha hecho a las costas del estrecho de Magallanes con recelo de enemigos de Europa por don Antonio de Vea (1886), Anuario Hidrográfico de la Marina de Chile, 11, 539-596; Viajes del piloto Francisco Machado a los archipiélagos occidentales de la Patagonia, 1768 (1889), Anuario Hidrográfico de la Marina de Chile, 14; Instrucciones reservadas que le dio el gobernador de Chiloé don Carlos de Beranger para la exploración de las costas australes de Chile, 1768, (1889), Anuario Hidrográfico de la Marina de Chile, 14, 71-77; Diario de la navegación hecho por el padre José García de la Compañía de Jesús, desde su misión de Cailín, en Chiloé, hacia el sur, en los años 1766-1767 (1889), Anuario Hidrográfico de la Marina de Chile, 14, 3-42; Diario del viaje de Cosme Ugarte a las costas occidentales de la Patagonia, 1767-1768 (1889), Anuario Hidrográfico de la Marina de Chile, 14, 49-55; Exploraciones geográficas e hidrográficas de José de Moraleda y Montero (1888). Documentos para la Historia de la Náutica en Chile. Santiago: Imprenta Nacional.

18 Amat y Junient, M. [1760] (1924-1928). Historia geographica e hidrográfica con el derrotero general correlativo al plan del reino de Chile que remite a Nuestro Monarca el Señor Don Carlos III, Revista Chilena de Historia y Geografía, 53-62; Brizuela, M. [1750] (1916). Primer viaje de exploración a la isla de Tenquehuen, Revista Chilena de Historia y Geografía, 23, 5-31.

19 Alfonso, J. [1931] (1966). ¿Todavía la Patagonia? Revista Chilena de Historia y Geografía, 134, 82-85; Amunátegui, M. (1879-1880). La cuestión de límites entre Chile y la República Argentina, Santiago: Imprenta Nacional; Anrique, N. (1984). Bibliografía Marítima Chilena, Santiago: Imprenta Cervantes; Bazán, R. (1986). El patrimonio que recibimos del Reino de Chile. Santiago: Instituto de Investigaciones 
El objetivo de este artículo es analizar parte de la historia del territorio reconocido como Patagonia Insular Occidental ${ }^{20}$, que comprende también las costas de la tierra firme continental, desde la latitud del archipiélago de las Guaitecas, por el norte, a la boca occidental del estrecho de Magallanes, por el sur. No fue un territorio de ocupación española, y las relaciones con los grupos indígenas fueron las propias de las fronteras. Interesa aquí estudiar los hechos de los españoles o hispano-criollos en ese territorio durante el período colonial, porque esos hechos o actividades revelan actitudes ante el mismo, que a su vez son originadas por la imagen que de ese territorio que se va construyendo según el interés que se tiene en él. Entendido como un proceso en el cual esa zona va adquiriendo significados para Occidente, se distinguirán hitos, etapas y motivaciones. Para hacerlo, hemos tenido a la vista todos los documentos de archivo sobre viajes a las costas de la Patagonia occidental, y en su defecto, a los ya publicados. Pertenecen a fondos nacionales, principalmente el Archivo Nacional Histórico, de Santiago, con sus fondos Capitanía General, Varios, Vidal Gormaz y Morla Vicuña; y a fondos extranjeros, en forma especial el Archivo General de Indias, de Sevilla, el del Museo Naval de Madrid, y el de la Compañía de Jesús, en Roma. En su gran mayoría es correspondencia entre autoridades de Madrid, Lima, Santiago y Chiloé; instrucciones a comandantes de expediciones; diarios y reportes; y otra información dispersa en obras de

del Patrimonio Territorial de Chile, Universidad de Santiago; Donoso, R., Irarrázaval, J. (1966). Barros Arana y la pérdida de la Patagonia. Revista Chilena de Historia y Geografía, 134, 67-81; Irarrázaval, J. [1930] (1966). La Patagonia. Errores geográficos y diplomáticos. Santiago: Editorial Andrés Bello; Monge, J. (1944, 1945 y 1946). El istmo de Ofqui. Revista Chilena de Historia y Geografía, 105, 5-44; 106, 62-102; 107, 296-338; 108, 117-156; Morla, C.(1903). Estudio histórico sobre el descubrimiento y conquista de la Patagonia y Tierra del Fuego. Leipzig: F.A. Brockhaus; Thayer, T. (1918). Cuestiones de Geografía austral de Chile. Revista Chilena de Historia y Geografía, 29, 161-217; Thayer, T. (1918). Estudio históricos sobre las regiones de los coronados y de los rabudos. Revista Chilena de Historia y Geografía, 32, 155-200; Thayer, T. (1919). Importancia que tenían para los españoles las regiones patagónicas. Revista Chilena de Historia y Geografía, 36, 324-342; Vidts, E. (1921). Ventajas de la apertura del istmo de Ofqui. Revista Chilena de Historia y Geografía, 42, 139-143.

20 Concepto acuñado por el antropólogo Daniel Quiroz, cuando en 1985 escribió La expedición del piloto Juan García Tao a la Patagonia Occidental Insular (1620-1621). Quiroz, D. (1985). distinta naturaleza, como la Historia general del reino de Chile, y la Conquista espiritual del reino de Chile, ambas de Diego de Rosales, o la Historia General de la Compañía de Jesús en Chile, de Miguel de Olivares, entre otros.

\section{EXPEDICIONES}

1. Expediciones enviadas desde Concepción y Valdivia para reconocer el estrecho de Magallanes, 2da. mitad del siglo XVI.

Desde la primera ocupación del territorio de Chile, los gobernadores tuvieron como objetivo reconocer y tomar posesión del estrecho de Magallanes, y probar el acceso norte-sur, desde la boca occidental a la oriental del límite austral conocido de las tierras emergidas en el Nuevo Mundo. Para recorrer y describir ese paso se despacharon tres expediciones desde España, entre 1526 y $1540^{21}$, y otras desde Chile, las que se desplazaron avanzando hacia el sur por el océano Pacífico. Éstas fueron dos: la primera comandada por Francisco de Ulloa, junto a los pilotos Hernán Gallego y Francisco Cortés Ojeda, Hojea u Ojea, entre octubre de 1553 y enero de $1554^{22}$; y la segunda, en 1557-1558, a cargo del comandante Juan Ladrillero, y Cortés Ojeda, Hojea u Ogea ${ }^{23}$.

La primera expedición, de tres naves, fue ordenada por el gobernador de Chile, Pedro de Valdivia. Partió la flota desde la recién fundada ciudad de Concepción, y avistó la costa occidental de la isla grande de Chiloé. A los 44 grados de latitud sur (según la graduación que da el documento) se perdieron de vista

21 Fray García Jofré de Loayza, 1526; Simón de Alcazaba, 1535 y Alonso de Camargo, 1540. Véase a Martinic, M. (1977). Historia del Estrecho de Magallanes. Santiago: Editorial Andrés Bello.

22 Barros, J. (1981). Expedición al estrecho de Magallanes en 1553: Gerónimo de Vivar y Hernando Gallegos. Anales del Instituto de la Patagonia, 12, 31- 40.

23 Véase Hermosilla, N., Ramírez, J. (1982). Reconstrucción autorizada de la expedición de Juan de Ladrillero a la Patagonia Occidental: 1557-1599. Anales del Instituto de la Patagonia, 13, 59-71. Y González-Barrera, J. (2010). La derrota a través del Estrecho de Magallanes: el viaje olvidado de Juan Ladrillero (1557-1559). Atenea, 501, 1133. También Oyarzún, J. (1999). Expediciones españolas al estrecho de Magallanes y Tierra del Fuego. Madrid: Ediciones de Cultura Hispánica. Este libro es interesante porque combina expediciones que se despacharon tanto por el océano Pacífico como por el Atlántico. 
y separaron las naves. Un camino siguió la comandada por Hernán Gallego ${ }^{24}$ y la de Cortés Ojeda, Hojea u Ogea -quienes también se separaron, a los 48 grados - , y otro la que iba al mando del comandante Ulloa ${ }^{25}$, donde iba a bordo también Jerónimo de Vivar, quien dejó la otra de las relaciones de esta expedición ${ }^{26}$. Esta última nave navegó por la costa occidental del archipiélago de los Chonos, avanzó hasta la latitud de 51 grados y medio, y desde allí emprendió su regreso, porque creyeron haber encontrado la boca occidental del estrecho de Magallanes, cuando en realidad se trataba de una ensenada. Por su parte, el navío de Gallego alcanzó, en diciembre de 1553, dicha boca del Estrecho, y lo recorrió, luego de lo cual regresó por falta de bastimentos, pero antes un temporal les hizo alcanzar tierra en la latitud 55 grados. Este fue el primer avistamiento de la costa patagónica occidental y la primera descripción de sus habitantes.

El gobernador García Hurtado de Mendoza envió la segunda expedición en 1557, en cumplimiento de una real cédula de fecha 29 de marzo de 1555, en que se ordenaba ampliar la jurisdicción del reino de Chile hasta el estrecho de Magallanes ${ }^{27}$. El objetivo fue hacer una toma de posesión, acto formal y ritual que para la corona española tenía validez de soberanía. La flotilla salió de Valdivia el 17 de noviembre de 1557, teniendo a Ladrillero como comandante, y nuevamente

24 Declaración del estrecho de Magallanes. Informe de Hernán Gallego sobre su viaje al estrecho de Magallanes, 1553-1554. Biblioteca del Congreso de Estados Unidos de América, Rare Books and Special Collections Division, The Hans P. Kraus Collection of Sir Francis Drake, Catalogue Item 1 "Memoria de la Costa Rica del Mar del norte [with three other narratives]", pp. 17-20, en: http://patlibros.org/ dlpdf/rhg.pdf. Este manuscrito sólo se conoció a mediados del siglo XX, cuando se incorporó a la citada biblioteca, donado por un librero.

25 Véase a Navarro, L. (1994). Francisco de Ulloa. Explorador de California y Chile austral. Badajoz: Departamento de Publicaciones, Excma. Diputación Provincial de Badajoz.

26 Vivar, Gerónimo de [1558] (1979). Crónica y relación copiosa y verdadera de los Reinos de Chile. Edición de Leopoldo Sáez Godoy. Berlín: Bibliotheca Ibero-Americana, Colloquium Verlag. Cap. CXX "Que trata de los puertos que descubrieron los navíos que envió el gobernador a descubrir el estrecho de Magallanes y en qué grados están", pp. 212 214. El manuscrito se encuentra en la Newberry Library, en Chicago.

27 Cédula con la que, dice Martinic, la actual región de Aysén, entonces incluida en el interminable concepto de la Trapananda, pasó a integrar el territorio de la gobernación o reino de Chile. Martinic, M. (2005), p. 52. a Hernán Gallego y a Cortés Ojeda, Hojea u Ogea, éste último a bordo de la San Sebastián, donde también iba el escribano Goicueta, quien dejó una relación ${ }^{28}$. En su diario $^{29}$, Ladrillero expresa el objetivo de la empresa, que es dar la Relación, derrotas y altura y señales de tierra, y calidad de ella, y traje y manera de la gente de cada provincia o bahía... Hernán Gallego naufragó en el cabo Tres Montes, a la altura de 47 grados. Ladrillero recorrió la costa oeste del archipiélago de los chonos y dio sus impresiones: la tierra es alta, montuosa y de muchas aguas y rebolones, y de muchas costas que entran la tierra adentro, donde al parecer no vio indios, o no los describió, y dio razón del golfo de Penas, que llamó ensenada del Alcachofado. Aquí describe a los indígenas como de mediano cuerpo y muy rústicos. La primera tierra que describe el escribano Goicueta es el área del golfo de Penas, donde nombró a una bahía Nuestra Señora del Valle, a 47 grados y 53 minutos: La tierra que terminaba la vista desde esta dicha bahía está en la costa dos o tres leguas tierra baja montuosa y más la tierra dentro serranía doblada, cuyos cerros por arriba blanqueaban de piedras peladas y por abajo montuosos y más tierra adentro aparecían muchas sierras altas nevadas. Pronto se encontraron con indios que les hacían señas desde la tierra con altas voces, bailando y capeándonos con unos manojos de plumas de patos. Continuaron por las costas patagónicas hasta lograr su objetivo, haciendo un segundo reconocimiento del Estrecho.

Ambas expediciones contaron con tres naves cada una, navegaron por la costa patagónica teniendo a la vista islas y bahías, bajaron a tierra varias veces, describieron por primera vez aquella geografía vista desde el mar, nominaron el territorio, e interactuaron y describieron a los habitantes australes occidentales, siendo todos estos actos de soberanía. Después, durante el resto del siglo, la Corona no envió a otros reconocimientos desde Chile - aunque se refiere una expedición en $561^{30}$

28 Derrotero de Cortés Ogea que fue con Juan Ladrillero en el navio San Sebastián, 1557. AGI, Patronato, 32, R. 5 , 110 imágenes, disponible en el portal de archivos españoles, www.pares.mcu.es.

29 Descripción del viaje de Juan de Ladrillero: Estrecho de Magallanes. AGI, Patronato 33, N.1, R.1, 61 fojas, también disponible en www.pares.mcu.es.

30 Se trata de una expedición oficial en tiempos del gobernador Francisco de Villagra (1561-1563) a cargo de Juan López de Porres y Juan Álvarez de Luna, con el objetivo de dar información sobre la tierra situada al sur del golfo de los 
-, y en lo sucesivo, es la provincia de Chiloé quien se encarga de navegar hacia el Estrecho. Por otra parte, reconocimientos como éstos son habituales en las fronteras americanas del siglo XVI, cuando se buscaba perfilar los márgenes del continente, explorar rutas de navegación, y buscar posibilidades estratégicas y económicas. Por entonces, la navegación por el sector más meridional de la mar del Sur era nueva, mientras que por la tierra firme, los españoles habían alcanzado hasta la latitud de Valdivia (40 grados), pero aún no se fundaban ni Osorno ni Castro.

2. Malocas o entradas para "coger piezas", salidas desde Chiloé a fines del XVI y primeras décadas del XVII.

La ciudad más meridional fundada por la corona de Castilla en las Indias fue Santiago de Castro, que data de 1567, en la isla grande del archipiélago de Chiloé, a 42 grados y medio de latitud sur. Los españoles poblaron el archipiélago, se repartieron mercedes de tierras y encomiendas de indios - a quienes se les llamó veliches -, y comenzó a desarrollarse, en esta geografía insular, el sistema colonizador castellano. Como en otros lugares de frontera en América, en las etapas iniciales de la conquista y colonización los españoles presionaron sobre los indígenas no sometidos de sus márgenes, con el objetivo de mantener quietas o sujetas sus fronteras y asegurar la estabilidad del centro. Desde Chiloé, provincia lejana del centro del reino, las entradas o malocas -incursiones cortas y rápidas, ejecutadas por los vecinos del archipiélago, para mostrar la superioridad española y capturar individuos o piezas, para venderlos como esclavos en la feria de Chiloé- estuvieron dirigidas a los indígenas de su frontera norte (juncos), nororiental (nahuelhuapis) y sur (chonos), y se practicaron desde

Coronados, es decir, Chiloé. Habrían navegado por el mar interior de Chiloé, el golfo de Corcovado y hacia el sur, ignorándose hasta dónde. Martinic, M. (2005), p. 52, quien lo refiere de Morla, C. (1903), Apéndice, p. 187. También Urbina, R. (2004). Población indígena, encomienda y tributo en Chiloé: 1567-1813. Política estatal y criterios locales sobre el servicio personal de veliches y payos. Valparaíso: Ediciones de la Universidad Católica de Valparaíso, p. 87, y cita a "Francisco de Villagra a Diego de Acevedo, virrey del Perú", en Campos, F. (1969). Don García Hurtado de Mendoza en la Historia Americana. Santiago: Editorial Andrés Bello, p. 84. Véase también Vázquez de Acuña, I. (1977-1978). El descubrimiento y conquista de Chiloé, Boletín de la Academia Chilena de la Historia, 90, 129163, p. 146. fines del siglo XVI, al igual que en otras ciudades del reino de Chile ${ }^{31}$.

La ejecución de malocas fue la primera modalidad de exploración de las costas patagónicas desde Chiloé, cuando, a comienzos del siglo XVII, desde Chile había bajado el interés por descubrir, explorar y poblar el estrecho de Magallanes, debido a las bravías condiciones naturales que habían demostrado los viajes precedentes, a la falta de hombres y recursos para la empresa, y a las enormes dificultades después del desastre de Curalaba, de $1598^{32}$. Entonces, la atención a la Patagonia vino desde Chiloé, y mas que al Estrecho, hacia su sección norte, debido a su proximidad y continuidad geográfica. Se navegaba con indígenas amigos, guías, pilotos y remeros indígenas, por el golfo de Corcovado hacia los archipiélagos de las Guaitecas y de los Chonos, recorriendo el canal Moraleda y canales interiores, en una acción con fines comerciales -captura de individuos para ser vendidos -, pero no de reconocimiento geográfico ni tampoco de anotaciones cartográficas. De ellas no ha quedado ninguna descripción, sino sólo breves menciones. La relación de los españoles con los chonos y otras etnias fue, desde entonces, de sujeción, aumentada por la enorme diferencia cultural entre ambos grupos: el pueblo chono era bordemarino e itinerante en un mundo archipielágico ${ }^{33}$-la antítesis de los valles, cordilleras y quebradas castellanos-, no practicaba la agricultura y su modo de vida estaba definido por la dalca, su embarcación, hecha de tres tablones cosidos y calafateados ${ }^{34}$.

31 Jara, A. (1971). Guerra y sociedad en Chile: la transformación de la Guerra de Arauco y la esclavitud de los indios. Santiago: Editorial Universitaria.

32 Martinic, M. (1992). T. I, p. 249.

33 Urbina, R. (2007). El pueblo chono: de vagabundo y pagano alzado a cristiano y sedentario amestizado. En F. Navarro (Ed.). Orbis Incongnitus. Avisos y Legajos en el Nuevo Mundo. Homenaje al Profesor Luis Navarro García. Vol. I. (pp. 325-338). Huelva: Publicaciones de la Universidad de Huelva.

34 Latcham, R. (1930). La dalca de Chiloé y los canales patagónicos. Boletín del Museo Nacional de Historia Natural, 13, 63-72; Finsterbusch, C. (1934). Las dalcas de Chiloé y los chilotes. Santiago: Imprenta Universitaria (también, y en el mismo año, en Revista Chilena de Historia y Geografía, 82, 412-433; Medina, A. (1984). Embarcaciones chilenas precolombinas. La dalca de Chiloé. Revista Chilena de Antropología, 4, 121-138; Urbina, R. (1986). La dalca chilota de los siglos XVII y XVIII. Chiloé, 6. Puente, M. (1986). La "dalca" de Chiloé. Su influencia en la exploración austral. 
Dice Fernando Casanueva que los españoles de Chiloé organizaban periódicamente desde fines del siglo XVI incursiones esclavistas entre los chonos, quienes eran transportados por mar y vendidos en el centro del reino ${ }^{35}$. Contamos con pocos, pero elocuentes datos, sobre estas incursiones con fines esclavistas ${ }^{36}$. Se sabe de una entrada al sur de Chiloé que hizo Diego Mazo de Alderete, corregidor de Castro, a poco de ser fundada esta ciudad, ocasión en la que se estimó en 200.000 los indígenas que habitaban mas de 1.500 islas pobladas ${ }^{37}$. Es posible suponer que en lo sucesivo el número de capturas debió ser alto -aunque nada sabemos de cifras, por ser una práctica ilícita-, porque los chonos apenas se estimaban en par de cientos a mediados del siglo XVIII. La justificación para la acción era que con la esclavitud y el traslado se conseguiría la evangelización y desbarbarización de los indigenas, que de permanecer éstos en sus islas no sería posible. Esta razón subyace en las correrías al margen sur de la provincia de los siglos XVI y XVII.

Cuando los jesuitas llegaron por mar a Carelmapu en 1609 para hacerse cargo de la misión de Chiloé, y aunque era sólo una escala a su destino final de Castro, se detuvieron allí más de un mes, sorprendidos -según Pedro de Lozano- por la magnitud del negocio a que estaban entregados los soldados: la inicua grangería de comprar o vender indios ${ }^{38}$, de las provincias fronterizas de Chiloé: el área junco-huilliche, y las islas de los chonos. Los misioneros lograron en parte poner freno a la captura. Hacia 1613 el jesuita

Contribución a su estudio. Revista de Historia Naval, 15, 19-44; Urbina, X. y Chapanoff, M. (2010). El protagonismo de la dalca en las navegaciones australes coloniales. Actas de las Jornadas de Historia Naval y Marítima de Chile, 5, 63-72.

35 Casanueva, F. (1982). La evangelización periférica en el Reino de Chile. Nueva Historia, 5, 5-30, p. 20.

36 Urbina, X. (2013a), Traslados de indígenas de la Patagonia occidental insular a Chiloé en los siglos XVI, XVII y XVIII. En J. Valenzuela (Ed.). América en diásporas: esclavitudes y migraciones forzadas (siglos XVI-XIX). Santiago: Instituto de Historia, Pontificia Universidad Católica de Chile/RiL editores (en proceso de edición).

37 Mariño de Lobera, P. (1865). Crónica del reino de Chile, Colección de historiadores de Chile y documentos relativos a la historia nacional, T. 6, cit. en Casanueva, F. (1982), p. 20.

38 Lozano, P. (1755). Historia de la Compañía de Jesús en la Provincia de Paraguay. Madrid: Imprenta de la viuda de Manuel Fernández y del Supremo Consejo de la Inquisición. Vol, 2, cap. IV, p. 35.
Melchor Venegas señala que la población de las islas Guaitecas, de pocos años a esta parte ha ido en grande disminución, porque por la minuta que se hizo, ahora 10 ó 12 años, consta que había más de 15.000 varones de lanza, sin las mujeres e hijos chiquitos, y ahora no hay más de 3.000 almas, grandes y chicos, en toda la isla, a causa de las que han ido sacando cada año los navios que allá van, y sólo ahora dos años, con estar alli los de la Compañía, que los estorbábamos cuanto podíamos, sacaron al pie de 400 y los traen a vender acá abajo, es decir, en Chile Central ${ }^{39}$. Otro de los pocos datos es el que consigna Juan Contreras y su equipo, quienes dan cuenta de un caso de venta de indígenas por parte de otros indígenas. Se trata de una denuncia de 1621 en contra el cacique chono Diego Delco, quien ha tomado tanta mano que anda vendiendo públicamente [...] los chonos, sus sujetos, y entra a maloquear a los de otras encomiendas para el mismo objeto, con notable agravio y manifiesta injusticia de dichos indios [...] y todos los navios que salen de la provincia y los más de ellos van cargados de chonos, allá los venden como esclavos ${ }^{40}$. A su vez, los chonos capturaban a sus vecinos del sur, los huilles, aunque no sabemos si esto comenzó como consecuencia de las malocas hacia ellos: suelen, los más ladinos de los chonos, irlos a maloquear [a los huilles], y se sirven de ellos, y aun los venden o dan en don a otros ${ }^{41}$. Y en 1611 se veían huilles en Chiloé, porque dice el jesuita Ferrufino: yo he visto a algunos que no sirven más que de ojear pájaros, porque no entienden la lengua general, ni son entendidos en la suy ${ }^{42}$. Pero no podemos saber para los siglos XVI, XVII y XVIII cuántos chonos u otros grupos había en los embarques a Chile de indios de Chiloé, porque no hay cifras ni destinos ${ }^{43}$. Menos aún

39 Carta Anua de 1610 (fechada en 5 de abril de 1611), en AA.VV. [1609-1614] (1927). Cartas Anuas de la Provincia del Paraguay, Chile y Tucumán, de la Compañía de Jesús (1609-1614), Documentos para la historia argentina, T. XIX. Buenos Aires: Talleres S.A. Casa Jacobo Peuser, Ltda., p. 108.

40 Contreras, J., Flores, E., Hererra, I., Mazzei, L., Rivera, A. y Romero, R. (1971). La población y la economía de Chiloé durante la Colonia, 1567-1826: un ensayo de interpretación. Concepción: Universidad de Concepción, p. 39, nota 49.

41 Extracto de la carta del P. Juan Bautista Ferrufino, contenida en la Carta Anua de 1610 (fechada en 5 de abril de 1611), en AA.VV. [1609-1614] (1927), pp. 110-112.

42 Ibidem, p. 112.

43 Eso sí, hay al menos una noticia para 1625, en que según 
podemos saber cuántos viajes de españoles o hispanocriollos de Chiloé - vecinos de Castro - hubo hacia las costas del sur, pero suponemos eran frecuentes, por el interés económico de una provincia pobre y aislada, y por poder valerse de guías y remeros indígenas de los que habitaban el mar interior de Chiloé, repartidos en encomiendas.

Las malocas a los chonos, por lo tanto, no constituyeron ocupación de la costa patagónica, ni exploración sistemática de ella que haya dejado registros geográficos y cartográficos, ni tampoco constituyeron interacción permanente con sus habitantes, pero si permitieron a los habitantes españoles de Chiloé conocimiento y experiencia en las costas mar interior al sur de Chiloé, no proporcionado por las expediciones salidas desde Concepción y Valdivia, que navegaron por mar afuera.

3. Visitas misionales a los archipiélagos de las Guaitecas y de los Chonos, $1^{a}$ mitad del siglo XVII.

Las malocas hacia las islas de los chonos ${ }^{44}$ despertaron el interés de los jesuitas por los indígenas más alejados de Chiloé apenas desembarcaron en la Provincia, en el puerto de Carelmapu, en 1609. Fue determinante el comienzo de la interacción en las Guaitecas la llegada a Chiloé para comerciar en el invierno de ese mismo año, de un indígena chono ${ }^{45}$. Los jesuitas le llamaron Pedro Delco ${ }^{46}$, y le reconocieron como cacique de los chonos. Por medio de otro chono con el que llegó, muy ladino en la lengua asimismo general, y ante las preguntas de los interesados, dio

carta de ese año de un vecino de Castro, desde 1607 había algunos chonos en La Serena, Concepción y Chillán. "Demanda presentada por el capitán Guisepe de Vargas, vecino encomendero de Castro, en nombre de su hermana Catalina de Vargas, contra el teniente Pedro Muñoz de Alderete y su mujer Catalina de Mendibi por la posesión de una encomienda de Chonos" (Santiago, 1625), ANH, RA, Vol. 1691, pza. 15, fjs. 251-263v.

44 En el período colonial, desde Chiloé se llamaban islas de los chonos, a las islas Guaitecas, aunque también se les denominaba islas Guaitecas, porque era el lugar donde se hallaba el grupo étnico chono. Mas al sur, precisamente en el archipiélago que hoy llamamos de los Chonos, los españoles casi no vieron indígenas.

45 Extracto de la carta del P. Juan Bautista Ferrufino, contenida en la Carta Anua de 1610 (fechada en 5 de abril de 1611), en AA.VV. [1609-1614] (1927), p. 112.

46 Quiroz y Olivares (1988). a entender lo numeroso de su pueblo, lo que motivó a los jesuitas a llegar hasta sus islas para misionarlos, viajes posibilitados por los indígenas de Chiloé, quienes hacían de pilotos y remeros en sus dalcas, de la misma manera que asistían en la misión circular, por el mar interior de Chiloé.

La carta anua de 1609 da la primera noticia de esas islas, vistas desde Chiloé y dando cuenta de las malocas a los chonos. Luego de hablar de las islas de Chiloé, ubicándolas a una distancia entre 35 y 40 leguas del Estrecho, dice que: Hay alli cerca noticia de otro archipiélago a otra tanta distancia de otra tanta gente en menos islas, con quien los primeros contratan y dicen que es una gente de poquísima capacidad $^{47}$. La carta anua de 1611 retrata a los chonos y su espacio geográfico - La otra parte de la isla [de Chiloé] que mira al sur dista como doce leguas de otro archipiélago de islas, que llaman de los Chonos y Huilles -, por referencias de Pedro Delco, por lo que se deduce que hasta esa fecha no había habido viaje de jesuitas. Eso sí, Delco volvió a Chiloé todos los años, es decir, desde 1609 a $1613^{48}$. Muy probablemente a fines de 1613 o en enero de 1614 (dicen que para Cuaresma ya estaban de regreso en Chiloé) viajaron al archipiélago de los Chonos los jesuitas Melchor Venegas y Mateo Esteban. Explican que durante esas semanas hicieron levantar cuatro ranchos a maneras de capillas, para atraer la población dispersa en islas, que no pasó de 120 individuos. Los jesuitas dan relevante información etnográfica sobre las características físicas de los chonos, su alimentación, vestimenta, etc.

Los viajes misionales a los chonos fueron dos hasta 1620, como se dice en la carta anua de ese año ${ }^{49}$. En la anua de 1623 se lee que el jesuita Agustín Villaza, misionero en Chiloé, estimulado por su celo, pasó a las islas de los Chonos, y es de opinar que sacaría abundante fruto ${ }^{50}$. No se refiere otra expedición

47 Extracto de la Carta Anua, 1609, del P. Diego de Torres, Córdoba del Tucumán, 17 de mayo de 1609, en AA. VV. [1609-1614] (1927), p. 22.

48 Adiciones a la carta anua de 1611, ARSI, Provincia de Chile, Vol. 8, f. 73.

49 A esta nación de indios han ido los padres dos veces con grandes riesgos de sus vidas, Cartas anuas de la Provincia del Paraguay de los años 1618 y de 1619, Córdoba, 7 de febrero de 1620, ARSI, Provincia de Chile, Vol. 8 , f. 195.

50 Techo, N. [1673] (2005). Historia de la provincia del Paraguay de la Compañía de Jesús. Asunción: Centro de Estudios Paraguayos Antonio Guash, Fondec. Libro Séptimo, cap. VI, p. 359. 
misional sino hasta 6 años más tarde, cuando otra vez el jesuita Melchor Venegas fue a las islas de los chonos, en 1629, acompañado por el misionero Juan del Pozo. En esta ocasión, el acceso a los archipiélagos al sur de Chiloé no fue navegando el golfo de Corcovado, sino que siguiendo el borde costero continental frente a las islas ${ }^{51}$. Alli estuvieron entre los chonos, buscando o cazando aquellas almas muchos días ${ }^{52}$, hasta que regresaron a Chiloé, en el mismo verano. Ese viaje, probablemente haya sido motivado por las nuevas etnias conocidas en la expedición de Juan García Tao, de 1620, que llegó hasta la altura del archipiélago de Guayaneco. Otros viajes a las islas al sur de Chiloé fueron los del jesuita Juan López Ruiz, que se conocen por la inédita Conquista espiritual del reino de Chile, de Diego de Rosales. No sabemos en qué año fue el primer viaje, pero el año más temprano posible sería de $1631^{53}$, en que fue a los chonos atravesando aquellos tempestuosos mares y procelosos golfos. Durante el tiempo que alli estuvo - en el verano - tuvo contacto con el cacique Francisco Delco, probablemente hijo de Pedro. Tampoco sabemos cuántos viajes hizo para visitar a los chonos y en qué años, sólo que de ordinario los iba a visitar como apóstol el P. Juan López Ruiz o enviaba otros de sus compañeros que los visitasen ${ }^{54}$.

51 La carta anua de 1629-1630 dice así: Para facilitar el camino y obviar el riesgo de las travesías de mar pasan un pedazo de cordillera muy agraz de más de 14 leguas, en que padecen excesivos fríos por estar muy llena de nieve y haber de hacer necesariamente su camino a pie. Después de la cordillera entran en un golfo de 10 leguas muy peligroso. Luego ensenadas de islas muy remotas, donde hallan el tesoro de las margaritas preciosas. Letras anuas de esta provincia de Chile de los años 1629 y 30, Firmada por Gaspar Sobrino, en Santiago, 2 de abril de 1631, ARSI, Provincia de Chile, Vol. 6, fjs. 63v-64v.

52 Olivares, M. [1736] (1874). Historia de la Compañia de Jesús en Chile (1593-1736), Colección de historiadores de Chile y de documentos relativos a la Historia nacional, T. VII. Santiago: Imprenta Andrés Bello, p. 376.

53 No se da una fecha de los sucesos que se relatan en este escrito, pero se dice que López Ruiz estuvo 30 años en Chiloé. Los sucesos entre el padre y los chonos, que transcribimos, dicen ser bajo el gobierno de Dionisio de la Rueda, que fue gobernador de Chiloé en 1631, 1641, 1644 y 1647, en todos los casos como interino. Urbina, R. (1998), p. 17.

54 Rosales, D. [c.1670] (1991). Vida del Padre Juan López Ruiz, en Valdés, G. (Introducción, Traducción y Notas). Seis misioneros en la frontera mapuche (Del Libro IV de la Conquista Espiritual del Reino de Chile, Volumen I, de Diego de Rosales). Temuco: Centro Ecuménico Diego
La última referencia que se tiene de este impulso misional al archipiélago de las Guaitecas es de una carta de Juan del Pozo, de 1639, donde se explican las razones del porqué cesaron estas esporádicas visitas estivales de la década de 1610: A la provincia de los chonos, se dice, entraron antiguamente los nuestros y recibieron de corazón la fe; pero ya por falta de obreros y lo mucho que tenemos que hacer en la islas primeras [las de Chiloé], no podemos entrar, sino es que $V$. reverencia socorra con algunos padres ${ }^{55}$.

Estos pocos viajes misionales se concentraban en el archipiélago de las Guaitecas, y no en el de los Chonos. A diferencia de la misión anual circular de Chiloé, estas muy contadas visitas a las Guaitecas no fueron misiones anuales, sino misiones volantes esporádicas ${ }^{56}$. Dado que se decía que las islas Guaitecas estaban pobladas (en la primera incursión se habla de 120 personas), es más factible que, siendo tan corta la estancia, los dos jesuitas se asentaran en uno o más parajes de ellas, y no que se aventuraran al extenso archipiélago de los Chonos. Una referencia posterior dice que la autoridad del cacique Pedro Delco era reconocida hasta ocho jornadas de viaje al sur de las Guaitecas, según el propio Delco ${ }^{57}$, de lo que se deduce que aun cuando los jesuitas no exploraran el archipiélago hoy llamado de los Chonos, pueden haber congregado en las Guaitecas, al menos con ocasión de sus visitas, a chonos cercanos y lejanos. Además, desde temprano (1611), informándose los jesuitas a través de los chonos, supieron de la existencia de otro pueblo, los huilles, habitantes más australes que éstos, distintos y más ladinos, tanto que los chonos los capturaban como servidores ${ }^{58}$. Juan del Pozo, en 1639 ,

de Medellín, Ediciones de la Universidad de la Frontera, p. 223.

55 Memorial y carta en que el padre Alonso de Ovalle, procurador general de la Provincia de Chile, representa a N. muy Reverendo Padre Mucio Vitilesqui, prepósito general de la Compañía de Jesús, la necesidad que sus misiones tienen de sujetos para los gloriosos empleos de sus apostólicos misioneros, Sevilla, 12 de marzo de 1642, ARSI, Provincia de Chile, Vol. 4, f. 78. Está impresa.

56 Moreno, R. (2007). Misiones en Chile austral: los jesuitas en Chiloé, 1608-1768. Sevilla: Consejo Superior de Investigaciones Científicas, Escuela de Estudios HispanoAmericanos, Universidad de Sevilla y Diputación de Sevilla, p. 189.

57 ANH, VG, Vol. 9, pza. 16, fjs. 440-441.

58 Los huilles, que viven mas hacia el Estrecho van totalmente desnudos; tienen las carnes negras (entiendo que es de 
logró contactarse por medio de un mensajero con el cacique Talcapillán, que habitaba cerca del estrecho de Magallanes, a cuarenta leguas de la ciudad de Castro $^{59}$, quien propuso ir con toda su gente a una isla que estaba a veinte leguas de allí, en la mitad del camino, y alli le aguardaría. Que ellos, como hijos de mar y criados en aquellos golfos, no tenian recelo de atravesarlos ${ }^{60}$, encuentro que se concretó en una isla que López llamó Deseada.

Las cartas anuas de los jesuitas mencionan la proximidad de las islas de los chonos al estrecho de Magallanes, como llamando la atención a que esas tierras y esos indios serían un vínculo entre Chiloé y el Estrecho. Refieren la existencia de otras naciones o etnias hacia el sur, o de forma genérica, por ejemplo: Después de esta provincia [de los chonos] se siguen otras hasta el mismo Estrecho, de varias naciones, y todas en muy buena disposición de recibir la fe, si hubiera quien se la predicase ${ }^{61}$, o especificando con el nombre de huillis o el cacique Talcapillán, que eran los mas australes.

La principal fuente de información de estas llegadas europeas al archipiélago de las Guaitecas son las cartas anuas, en las que se describe sucinta pero agudamente la nueva geografía revelada: mares tempestuosos que implicaban pasar por muchos $y$ grandes peligros y sufrimientos; el ímpetu del golfo de Corcovado; la dalca indígena como única herramienta posible, por ser marinera; las costumbres de los chonos;

las continuas injurias del sol y aguaceros y de las malas comidas, porque no comen mas que marisco crudo); tienen el cabello negro y gordo, como cerdas, son mas broncos y groseros, aunque no son feroces sino humildes y mansos. Sus casas son movedizas, porque haciéndolas como un toldo de cortezas de árboles, dobladizas, las mudan do quieren. Suelen, los más ladinos de los chonos, irlos a maloquear, y se sirven de ellos, y aun los venden o dan en don a otros. Extracto de la carta del P. Juan Bautista Ferrufino, contenida en la Carta Anua de 1610 (fechada en 5 de abril de 1611), en AA.VV. [1609-1614] (1927).

59 Letras anuas de esta provincia de Chile de los años 1629 y 30, Firmada por Gaspar Sobrino, en Santiago, 2 de abril de 1631, ARSI, Provincia de Chile, Vol. 6, fjs. 63v-64v.

60 Vida del Padre Juan López Ruiz. Rosales, D. [c. 1670] (1991).

61 Memorial y carta en que el padre Alonso de Ovalle, procurador general de la Provincia de Chile, representa a N. muy Reverendo Padre Mucio Vitilesqui, prepósito general de la Compañía de Jesús, la necesidad que sus misiones tienen de sujetos para los gloriosos empleos de sus apostólicos misioneros, Sevilla, 12 de marzo de 1642, ARSI, Provincia de Chile, Vol. 4, f. 78 . las orografía de las islas, su vegetación, y sus mariscos. Si el mar interior de Chiloé era un ámbito mas indígena que español, y cada salida misional en verano era un desafío, mucho más lo era el archipiélago de las Guaitecas y el paso por el golfo de Corcovado, tanto así que se exploró una ruta más larga (costeado la tierra firme) para evitarlo. Aun así, estas islas, antes sólo atacadas, desde entonces fueron descritas -eso sí, no se vio ningún interés económico en ellas- y formaron parte de las cercanías de Chiloé. Desde ellas, y sus habitantes, se comenzó a tener conocimiento de la magnitud de los archipiélagos australes. Por otro lado, junto con la atención espiritual de chonos y la esperanza de hacerlo con otros grupos, desde un comienzo a los jesuitas los mueve el interés por atender también a poblaciones españolas aisladas, o sus descendientes.

\section{Expediciones de búsqueda de los Césares, 1620-1676.}

La interacción, aunque ocasional, de los jesuitas con los indígenas en el archipiélago de los chonos, acentuó la creencia en la existencia de una colonia de españoles o extranjeros, aislada, en algún punto desconocido de la Patagonia, tanto costera como del interior. Estas sospechas eran precedentes a la fundación de Castro y colonización de Chiloé, por cuanto se recordaba el naufragio de 1540, de una de las naves del obispo de Plasencia en la boca oriental del estrecho de Magallanes, cuyos 300 sobrevivientes llegaron a tierra. Estos españoles abandonados en la costa, se pensaba que se habrían desplazado hacia alguna latitud más al norte, caminando por la Patagonia, como lo habrían hecho también los sobrevivientes de las abandonadas dos colonias fundadas en el Estrecho en $1584^{62}$.

La primera expedición que salió desde Chiloé en busca de poblaciones ocultas, de la que se tiene noticia, fue la de Juan García Tao. Quizá tenga su origen en la información contenida en la primera carta anua, de 1609: Estas y algunas otras personas que han pasado adelante dan noticia de muchas naciones que están la tierra adentro, hacia el Estrecho, y dicen que es gente blanca y anda vestida, usan de lienzo. Llevaron los padres de orden de hacer diligencia y tomar más particular noticia de esto ${ }^{63}$. La expedición

\footnotetext{
62 Martinic, M. (1992). T. I, pp. 244-249.

63 Extracto de la Carta Anua, 1609, del P. Diego de Torres,
} 
de García Tao, marítima, se complementaba con una terrestre o continental, al mando de Diego Flores de León, que también partió desde Chiloé al sur llegando a las pampas patagónicas por la vía del lago Nahuelhuapi, frontera nororiental de Chiloé -, en una acción conjunta tanto marítima como terrestre, en el año 1620. Probablemente, ambas estuvieron motivadas no sólo por la creencia en colonias de españoles sobrevivientes, sino también por llegada de holandeses a atacar Chiloé y Valdivia, en 1600, que evidenciaron la vulnerabilidad del confín del continente y la falta de noticias sobre él. Salió de Castro, García Tao ${ }^{64}$, el 5 de octubre de ese año con tres dalcas - débiles piraguas maniobradas por indígenas - y cinco soldados en busca de las poblaciones llamadas Césares, por la costa sur de Chiloé hacia el E. de Magallanes ${ }^{65}$. Llevaba al indio Millacar como guía y lengua para Caicof, identificable con el istmo de Ofqui, lo que da cuenta que la navegación por el mar interior de la costa patagónica, el canal que hoy se llama Moraleda, y el acceso al golfo de Penas. En las Guaitecas estuvo con Pedro Delco y con su compañía, y dos dalcas mas, continuó hacia el sur. Cruzó el istmo de Ofqui, ruta que combinaba la navegación fluvial y lacustre, con un trecho terrestre, que se transitaba desarmando las embarcaciones, y que evitaba remontar el temible golfo de Penas. En estas ocasiones -al parecer hubo más de una ruta en el istmo- se descosía la dalca y se llevaba al hombro, junto con la carga, por espacio de aproximadamente 15 kilómetros, para ser rearmada a la orilla siguiente, tanto en el recorrido de norte

Córdoba del Tucumán, 17 de mayo de 1609, en AA.VV. [1609-1614] (1927), p. 22.

64 Véase Quiroz, D. (1985).

65 Esta es la relación y viaje que hizo Juan García Tao hacia el estrecho de Magallanes..., ANH, VG, Vol. 9, pza. 16, fojas 437-448. No tenemos noticia del algún manuscrito de esta Relación, ni de otra versión de este viaje, más que la corta referencia de Rosales, D. [c.1670] (1877). Historia General del Reino de Chile. Flandes Indiano. Valparaíso: Imprenta del Mercurio, pp. 103 y 104. Francisco Vidal Gormaz dice que copió esta Relación de un manuscrito original de propiedad de Diego Barros Arana, quien halló esta relación en un grueso legajo de papeles que compró en Madrid a un mercader de libros viejos. Esos papeles parecían haber sido propiedad del capitán don Diego Flores de León, por cuanto en su mayor parte se referían a los servicios de este. Por lo demás, dice, ha visto en una carta de Flores de León al rey en que le habla del viaje de García Tao, recomendándole que se lleve adelante aquella exploración. a sur o vivecersa ${ }^{66}$. La expedición de García Tao pareciera ser la primera ocasión en que españoles o hispano-criollos utilizan esta ruta indígena. Después de él, ni las cartas anuas ni otras informaciones jesuitas del XVII la mencionan, porque no pasaron más al sur del canal Moraleda. Al otro lado de Ofqui, buscando las tierras de Allana y Guapof, el grupo se encontró en un balcón de islas de gente muy belicosa que los atacó. Hablaban lengua distinta y no hubo forma de comunicarse con ellos, a pesar de los acompañantes chonos. El 10 de diciembre el grupo comenzó su regreso a Chiloé sin haber encontrado a los españoles perdidos, pero con mas noticias sobre ellos, como que delante de más islas que se decían Guapash estaban los españoles, y que tenían por noticia que estaban vestidos de pieles, y que eran blancos y rubios, algunos más ${ }^{67}$.

Desde 1620 hasta 1639 no tenemos noticia de otro viaje militar al sur, sino sólo las entradas jesuitas ya señaladas. En 1639 hizo una entrada hacia el Estrecho el alférez Diego de Vera por orden del general don Bartolomé Galeazo de Alfaro, y regresó en 1640. No hallaron las poblaciones buscadas, al igual que la anterior, pero capturaron a un indio llamado Atapa, el cual dijo que hacia el Estrecho había españoles blancos y rubios con barbas y que andaban vestidos al modo de los españoles de Chiloé ${ }^{68}$. Esta noticia generó en la provincia el rápido apresto de una entrada a confirmarla, que salió en 1641 comandada por el capitán Rodrigo Navarro, y en la que también asistió el jesuita Jerónimo de Montemayor ${ }^{69}$. Eran siete embarcaciones y 80

66 Urbina, X. (2010) La navegación por los canales australes en la Patagonia occidental insular en los siglos coloniales: la ruta del istmo de Ofqui. Magallania, 38(2), 41-67.

67 Esta es la relación y viaje que hizo Juan García Tao hacia el estrecho de Magallanes..., ANH, VG, Vol. 9, pza. 16, f. 447.

68 Rosales, D. [c.1670] (1877), p. 105. Rosales es la única fuente que refiere ese viaje.

$69 Y$ entre ellos, a pocas jornadas, dicen que están los indios Césares descendientes de españoles. Yentendemos que son aquellos indios como mestizos que descubrieron el padre Rodrigo Navarro con el padre Jerónimo de Montemayor cuando con siete embarcaciones de soldados los fueron a descubrir por la parte de Chiloé y de los chonos, y no pudieron llegar adonde dicen que están los Césares, porque falta de mantenimiento los detuvo. Letras annuas de la vice provincia de Chile a nuestro muy reverendo padre general Gostino Nikel, escritas por el padre Juan de Albiz, vice provincial de la vice provincia de Chile desde el año de 1657 hasta el de 1659, ARSI, Provincia de Chile, Vol. 
hombres, toda una expedición de envergadura. Durante el viaje, pasados los Chonos, encontraron junto al Estrecho una inmensidad de islas y de golfos muy tormentosos, y entrando por rios y ensenadas, se veían obligados a deshacer las piraguas en trozos y llevarlas a cuestas, cargando en sus hombros el matalotaje por montes y peñascos asperisimos, $y$ esto lloviéndoles tres meses sin resguardo ninguno ni poder secar la ropa, alojando en las playas del mar entre las peñas con gran peligro de las repentinas crecientes $^{70}$. Rosales identifica las provincias de Pucaqui, y mas adelante, las de Allana, y Guapastos, a la que pasaron con inmenso trabajo a buscar lengua. Alli cogieron noticias de al menos tres indígenas, de las que se dedujo que los viracochas podían ser o como los españoles, o más blancos y rubios, lo que implicaba la posibilidad que fueran extranjeros. Esta colonia estaría mas adelante, por lo que avanzaron hasta la provincia de los Gaviotas, o cau cau, quienes les atacaron. Sin más noticias, y reconociendo, eso si, algo mas hacia el sur (donde encontraron a los guapastos y a unos gigantes), se devolvieron, habiendo llegado, dice Rosales, a los 48 grados de latitud sur ${ }^{71}$.

De los 24 años siguientes no tenemos información de expediciones misionales ni en busca de Césares, hasta que en 1665 el gobernador de Chiloé, Cosme Cisternas, envió algunas piraguas al descubrimiento de los Césares, pero que no hallando nada y faltándoles el mantenimiento, se volvieron, sin que haya llegado a nosotros descripción

6, fjs. 282-282v.

70 Vida del Padre Juan López Ruiz. Rosales, D. [c.1670] (1991), p. 237.

71 Rosales, D. [c.1670] (1877), p. 106. Quizá como consecuencia de esta expedición, así como de otras, Alonso de Ovalle escribe en 1646, que al sur de Chiloé, hasta la boca del estrecho de Magallanes, no hay quien sepa cosa de cierto, porque la guerra con los araucanos ha tenido impedido el paso y, así, no se ha podido descubrir esta tierra por esta parte, pero por la de Chiloé han entrado algunos capitanes con quienes yo he hablado y me han dicho que han hallado noticias de que hay en aquella tierras muchísima gente y lugares muy ricos, aunque nunca han podido llegar a ellos por estar muy retirados y ser menester más fuerza de la que llevaban. De estas noticias hay muchas $y$ todos convienen en que la tierra es muy rica y fértil y consiguientemente habrá en ella muchos que la habitan. Es muy célebre la fama que corre de que por este distrito están los Césares, de que se ha hablado ya en su lugar. Ovalle, A. [1646] (2003). Histórica relación del reino de Chile. Santiago: Pehuén Editores, p. 572. alguna del viaje, sólo la referencia de Olivares $^{72}$. Carvallo Goyeneche, quien escribió a fines del siglo XVIII, también señala esta expedición, o quizás es otra, cuando afirma, sin dar fecha, que Don Cosme Cisternas Carrillo, gobernador de la provincia de Chiloé, aprovechó aquella pequeña seguridad para hacer nuevos descubrimientos por aquella parte. Descubrió en el archipiélago la isla de Guayquilabquen, situada sobre los cuarenta y siete grados de latitud austral, de grande extensión, con buen puerto y capaz de muchas embarcaciones ${ }^{73}$. Todavía en el gobierno de Cisternas Carrillo, hubo otra expedición de la que no sabemos ni aún su comandante, sólo que fue en ella el jesuita Nicolás Mascardi, con designio de descubrir tierras hacia la parcialidad de los Poyas en demanda de una población de gente europea que se decía estar situada por ese rumbo. El padre Mascardi trasmontó la sierra de Corcovado y penetró hasta los 46 grados. Halló un lago con los bosques de su ribera quemados, indicio de haber por alli algún pueblo. No intentó más por falta de víveres, y por ser corto el número de gente que le acompañaba ${ }^{74}$. Quizá se mantuvieron

72 Olivares, M. [1736] (1874), p. 389. Olivares fija este hecho en 1656. Sin embargo, Cosme Cisternas Carrillo no era gobernador de Chiloé en ese año, sino que lo fue en 1640 , como interino, y luego como titular de 1663 a 1665, según Urbina, R, (1998), p. 17.

73 Carvallo Goyeneche, V. [1796] (1865). Descripción históricojeográfica del reino de Chile por don Vicente Carvallo $i$ Goyeneche, precedida de una biografía del autor por don Miguel L. Amunátegui, Colección de historiadores de Chile $y$ de documentos relativos a la Historia Nacional, T. IX. Santiago: Imprenta de la Estrella, p. 144. Se deduce que la expedición ocurrió en el año 1665, pero puede haber sido un año antes o uno después. Según Francisco Fonck, basándose en Diego de Rosales (Conquista espiritual), estuvo a cargo de este viaje el capitán Juan Velásquez Alemán, y que en ella participó nuevamente el jesuita Jerónimo de Montemayor. Fonck, F. (1900). Viajes de fray Francisco Menéndez a Nahuelhuapi. Valparaíso: Imprenta Guillet, p. 31.

74 Es la cortísima referencia que da Carvallo Goyeneche, V. [1796] (1865), T. IX, p. 144. Sin embargo, Fonck, basándose nuevamente en la Conquista espiritual de Diego Rosales, y en Amunátegui, M. [1879-1880], T. III, p. 91, cree que este viaje no fue realizado por Mascardi, sino por el piloto Juan Velásquez Alemán. Una segunda referencia es la que da el autor de la "Noticia breve y moderna" sobre Chiloé, cuando dice que Mascardi pasó a Ofqui antes de fundar misión en Nahuelhuapi, Anónimo, "Noticia breve y moderna del archipiélago de Chiloé, de su terreno, costumbres de los indios, misiones, escrita por un misionero de aquellas islas 
los patrullajes hacia el sur, no lo sabemos. Mateo Martinic detectó otra expedición a los Césares a través de un mapa existente en el Museo Naval de Madrid, posible de situarlo, dice, entre 1650 y 1670, que se realizó al mando del capitán Martín García Velasco, quien saliendo desde Chiloé, a las espaldas de la Guaitica halló esta laguna muy mansa y muy buenos patos que es bitam quem se puede entrar, 12 leguas mas allá del Guafo camino Martín Velasco río arriba en busca de la ciudad de los reyes a donde dicen está poblado el sr. obispo Argüello.... ${ }^{75}$. La siguiente expedición en busca de los Césares de la que se tiene noticia es la comandada por el sargento mayor Jerónimo Diez de Mendoza, motivada por el paso del oficial británico John Narborough por el Estrecho a fines de 1670, quien arribó a Valdivia en diciembre de ese año. Diez fue enviado por el gobernador de Chiloé, Francisco Gallardo, a que reconociese todo lo posible la costa desde dicha provincia hasta el dicho estrecho de Magallanes. Estuvo de regreso a comienzos de 1674, aunque no se sabe hasta qué latitud exploró, pero sí que no obtuvo noticias de que el enemigo de Europa estuviese en dicha costa ${ }^{76}$. Ya al menos

en el año 1769-1770", publicado por Hanisch, W. (1982), Apéndice, Documento VIII. Esta "Noticia" está en el ARSI, Provincia de Chile, Vol. 5, fjs. 345-383v. Y una tercera es de Olivares: que a Mascardi, estando en oración se le apareció el milagroso San Francisco Javier, su devoto, y le mandó que fuese a la conversión de los indios guaitecas, o chonos, hacia el Estrecho. Luego, sin tardanza, dispuso su viaje por aquellos mares arriesgados, que con el norte que le guiaba no se le ofreció peligro. Fue a los Chonos, donde convirtió a muchos, catequizando a los antiguos cristianos. Y habiendo corrido esas islas alumbrándolas con las luces de la verdad, se volvió al colegio, donde era preciso que asistiera para dar las providencias a las demás misiones, Olivares, M. [1736] (1874), p. 390. Véase Martinic, M. (1992), p. 257, quien cita a Rosso, G. (1950). Nicoló Mascardi missionario gesuita del Cile e della Patagonia (1624-1674). Archivum Historicum Societatis Iesu, 45, 3-74.

75 Martinic, M. (2005), p. 56. Se trata, dice el autor, del manuscrito de varias hojas titulado Carta hidrográfica del Perú, con mapas y descripciones parciales desde California hasta el cabo de Hornos, cuyo estudio ha sido hecho por: Martín, M. L. (1986). Derrotero de la costa pacífica americana. JANO 24-29 enero, 30, Vol. XXX, 709 (2) Medicina y Humanidades, p. 86. Martinic se refiere a la "Ilustración $\mathrm{N}^{\circ} 10$ ".

76 Se menciona su viaje en la expedición inmediatamente posterior, de Bartolomé Gallardo: Relación del sargento mayor don Bartolomé Gallardo hecha en Lima de orden desde al menos 1639, con la exploración de Diego de Vera, se hablaba expresamente de los Césares como extranjeros, y no como españoles. Diez de Mendoza condujo a Chiloé a algunos habitantes remotos, entre ellos a uno nombrado Talcapillán, cuyo nombre es el mismo que el jesuita Juan López Ruiz refiere del cacique más austral de los que conoció, 34 años antes.

Fueron interrogados, y específicamente Talcapillán dijo conocer una población de no españoles y no indígenas en algún punto del extremo austral, de la que dio detalles ${ }^{77}$, por lo que el gobernador de Chiloé, Francisco Gallardo, envió una expedición con el objetivo de confirmar las noticias, al mando de Bartolomé Gallardo. Salió en octubre de 1674 con siete embarcaciones, más piraguas y bastimentos, y se tiene noticia expresa que accedió a los canales del sur del golfo de Penas cruzando por el istmo de Ofqui ${ }^{78}$, tanto a la ida como al regreso, y llegando a Chiloé a fines de febrero de 1675. Esta expedición es la primera cuyo diario de viaje e información detallada ha llegado hasta nosotros, en el cual se detallan las jornadas, leguas andadas, y se señalan topónimos. Como en ella no se dan las latitudes, no se puede saber hasta dónde llegó, sólo que estuvo, al sur del istmo de Ofqui, en las costas de la tierra firme y en la isla de Llequelgue. Como capturó varios indígenas durante su periplo que le proporcionaron mas noticias sobre los extranjeros ocultos, fue con ellos - Talcapillán incluido - al Perú, a dar cuenta a virrey de las nuevas informaciones, que situaban a los Césares en dos parajes: Callanac y Ayanta o Ayauta.

Desde Lima, el virrey habilitó una nueva e inmediata expedición, al mando de Antonio de Vea, con navíos más grandes de los hasta entonces utilizados. Hasta este momento todas las expediciones habían sido enviadas desde Chiloé. Vea hizo su viaje desde Lima, con el navío Nuestra Señora del Rosario y Ánimas del Purgatorio, y dos barcos luengos (no especifica qué son) construidos para la ocasión, que estaban destinados a hacer el reconocimiento por fuera de los

$\mathrm{de} \mathrm{V}$. E. sobre el viaje que hizo en reconocimiento a las poblaciones de los ingleses con todo lo sucedido en él y paraje donde llegó, (1674-1675), AN, VG, Vol. 7, pza. 4, 19 fjs. También publicado en Anuario Hidrográfico de la Marina de Chile, T. XI, 525-537, y no se indica de dónde se obtuvo la copia o manuscrito.

77 Averiguaciones sobre ingleses, 1675, ANH, MV, Vol. 4, pzas. 187 a 191, 192 y 194-195, fjs. 444v-489.

78 Relación del sargento mayor don Bartolomé Gallardo. Anuario Hidrográfico de la Marina de Chile, T. XI, p. 531. 
canales, e iban al mando de Pascual de Iriarte ${ }^{79}$. Al aproximarse a Chacao, el navío naufragó en el canal de su nombre. Finalmente, desde Chiloé zarpó en noviembre de $1675^{80}$ comandando nueve piraguas, 70 españoles y 60 indios, haciendo el mismo recorrido de Gallardo, avanzando hacia el sur por el canal Moraleda, cruzando el istmo de Ofqui y saliendo al golfo de San Esteban, desde donde deshizo el camino. Llama la atención que describa con detalle las dificultades del camino terrestre por el istmo de Ofqui, con precisión del transporte de las piraguas por tierra, cuando el año anterior Gallardo apenas le dedicó una línea. Quizá sea porque para los españoles de Chiloé era una ruta de antiguo conocida, aunque no transitada, y porque en otros lugares de la provincia se avanzaba también con las piraguas desarmadas, como en el camino hacia el lago Nahuelhuapi, o en la tierra firme frente a la parte sur de la isla grande. Después de Vea no hay otra noticia de intentos oficiales de reconocimientos del sur de Chiloé.

Las expediciones en búsqueda de poblaciones ocultas durante el siglo XVII transitan desde el interés por encontrar sobrevivientes de náufragos o colonias del estrecho, a establecimientos de extranjeros holandeses o ingleses. Como se ve en la secuencia documentada, la primera expedición organizada ex profeso es en 1620 , y es contemporánea a las esporádicas visitas jesuitas al archipiélago de Guayaneco; en 1639 se envía a un militar a reconocer la zona austral, quien se informa, por medio de un indígena, de la existencia de europeos o no-indígenas hacia el sur. Desde entonces, se buscan noticias, y muy probablemente, o los indígenas dan informaciones erradas, o deliberadamente dicen a los españoles lo que quieren oír. Esto revela la movilidad

79 "Relación diaria del viaje marítimo y descubrimientos de las costas del sur que hizo por orden el excelentísimo señor conde de Castellar, marqués de Malagón, virrey, gobernador y capitán de estos reinos del Perú, Tierra Firme y Chile, el capitán de mar y guerra Pascual de Iriarte, en el navío Nuestra Señora del Rosario, que continuó en el de la Santísima Trinidad, desde la provincia de Chiloé hasta el estrecho de Magallanes y Tierra del Fuego, por el recelo de las poblaciones que se suponían hechas por el inglés en aquellas costas, siendo piloto mayor el capitán Guillermo Bautista de Echavarría. Año de 1675". MN 0145, Ms. 0191/005, fjs. 41-69.

80 Relación diaria que se ha hecho a las costas del estrecho de Magallanes con recelo de enemigos de Europa por don Antonio de Vea (1675-1676). Anuario Hidrográfico de la Marina de Chile, T. XI, pp. 525-537, p. 557. Vidal Gormaz señala que copió esta relación, en 1885, del Depósito Hidrográfico de la Armada, en Madrid. de los grupos canoeros y la información que adquirían de sus vecinos del norte, porque conocían los intereses y temores de los españoles de esa provincia

\section{Malocas en la segunda mitad del siglo XVII.}

Hay expediciones a la costa al sur de Chiloé durante la segunda mitad del siglo XVII que son entradas para capturar piezas. Abraham de Silva y Molina dice que Bartolomé de Vera Ponce de León hizo tres viajes al estrecho de Magallanes, uno de ellos bajo las órdenes del general don Antonio de Vea, los demás a su costa y mención ${ }^{81}$. En 1714 dice el alférez Alonso de Asencio Guerrero, que su padre, el sargento mayor Fernando de Asencio Guerrero sirve hace mas de 50 años en la compañía de caballos de dicha provincia, exponiendo su vida en varios viajes al estrecho de Magallanes ${ }^{82}$, o sea, desde 1665 . Ambos casos es posible que se refieran a las expediciones de Diez de Mendoza, Vea y Gallardo, u otras que no conocemos. Por su parte, en el juicio de residencia del gobernador de Chiloé Antonio Manríquez de Lara, que lo fue entre 1680 y 1683 , se le acusa de haber maloqueado a los chonos sin justificación, lo que indica que las acciones a los chonos aceptadas eran aquellas que se hacían como respuesta a sus ataques. De orden suya fue el sargento mayor Miguel Sánchez de Lezana a las tierras de Allana [...] y el resultado de la expedición fue maloquear 9 ó 10 piezas hembras y varones, los cuales despachó a la ciudad de Santiago, menos 3 indios que dejó en su servicio. El objeto de este viaje, además de coger piezas, era ver si había ciudad poblada de españoles por aquellos parajes ${ }^{83}$. Hasta fines del siglo XVII sigue habiendo alguna noticia de estas malocas, porque en tiempos del gobierno de Pedro de Molina (1692-1695), Fernando de Asencio fue enviado por cabo de 60 hombres a castigar a los chonos que infestaban las costas de la provincia ${ }^{84}$. Más tarde, un testimonio de 1725 habla de otras expediciones hacia las islas al sur de Chiloé para

81 Silva y Molina, A. (1899). ANH, FV, Vol. 141, f. 9.

82 Ibidem, f. 31.

83 Juicio de Residencia al ex gobernador Antonio Martínez de Lara tomado por su sucesor Antonio Ibáñez de Echeverri, Castro, 30 de mayo de 1684, en Silva y Molina (1899). ANH, FV, Vol. 139, fj. 22.

84 Silva y Molina, A. (1899). ANH, FV, Vol. 141, f. 58. Silva y Molina cita este documento en relación a la oposición a la encomienda de Henupuquén que hizo Alonso de Asenjo el año 1724, y lo refiere de ANH, CG. Vol. 487. 
castigar a los chonos porque éstos pasaban a la isla de Chiloé a robar ganado, llevarse indias, asesinar indios y quemarles sus casas. Por esta razón, Luis Álvarez de Bahamonde fue en busca de ellos en tres ocasiones. En el tercer viaje, en que anduvo por todas las islas de los Chonos, iba por cabo de diez hombres, pero no pudo encontrar ningún indígena ${ }^{85}$. Por último, contamos con dos datos más para capturas de indios a comienzos del siglo XVIII: el jesuita Miguel de Olivares informa en 1736 que hasta el año de 1706 sé que los chonos venían a maloquear a los de Chiloé, y los españoles con los indios los salian los a castigar $y$ traían muchas piezas o personas de mujeres $y$ muchachitos prisioneros ${ }^{86}$. Y, la información del hijo de José Pérez de Alvarado, quien hizo saber - con cierta exageración - que su padre, nacido en 1672, persiguió a los chonos hasta sus islas, sin dejar una sin recorrer hasta cerca de Tierra del Fuego, rompiendo y talando por muchas partes la Sierra Nevada, pasando hambres y fríos, manteniéndose con frutas silvestres y mariscos, dejando entre las ramas sus ropas a pedazos en busca de asilos, hasta las oscuras grietas y escondrijos, para guarecerse de las lluvias, muy abundantes en esas regiones tormentosas ${ }^{87}$.

Estos cortos datos permiten afirmar que, independiente de las expediciones de la segunda mitad del XVII en busca de los Césares, hubo otras que cubrieron mas islas del archipiélago de los Chonos, y no sólo las reconocidas como Guaitecas, con autorización del gobernador de la provincia, con el objetivo de castigar a los indígenas de su frontera sur y coger individuos para ser trasladados a Chiloé en condición de servidumbre.

\section{Expediciones como consecuencia del naufragio de la fragata Wager en Guayaneco (1741)}

No existen, hasta ahora, mas noticias de viajes de españoles hacia los archipiélagos australes después del de Antonio de Vea, 1675-1676, salvo las malocas. Quizá los hubo, enviados desde Chiloé para patrullar y descartar las sospechas que llevaron a Diez de Mendoza,

85 Silva y Molina, A. (1899). ANH, FV, Vol. 141, f. 69. Silva y Molina refiere este asunto cuando cita documentación de AHN, CG. Vol. 527, sobre la oposición a la encomienda de Nercón, en Castro, 1725.

86 Olivares, M. [1736] (1874), p. 373.

87 Guarda, G. (2002) Los encomenderos de Chiloé. Santiago: Ediciones de la Universidad Católica de Chile, p. 239.
Gallardo, y Vea al sur, y tal vez sean los mismos que cogieron piezas para trasladarlas a Chiloé ${ }^{88}$.

Martín Olleta, chono asentado en la isla de Chaulinec, del mar interior de Chiloé, fue quien halló en una de las islas del archipiélago de Guayaneco a sobrevivientes del naufragio de la fragata de guerra inglesa, Wager, ocurrido el 14 de mayo de 1741. Había formado parte de la flota, a cargo de George Anson, que zarpó en septiembre de 1740 desde Inglaterra para asediar las posesiones españolas del Pacífico ${ }^{89}$. Entre muertes por hambre, cansancio y enfermedades, y el regreso hacia el Atlántico de parte del grupo de náufragos en las embarcaciones auxiliares de la Wager, cuando llegó Olleta, a 9 meses del naufragio, había sólo 13 hombres, a quienes condujo a la isla grande de Chiloé, donde, famélicos y cansados de una ruta tan trabajosa, llegaron sólo 4 de ellos ${ }^{90}$. La presencia de Olleta en estos parajes, al sur del golfo de Penas,

88 Sabemos, sí, que quizá como producto de estas entradas que acabamos de reseñar, pero sobre todo de otras no documentadas -por no ser oficiales- o, en general, como consecuencia de la proyección española a aquellas islas, es que en 1710 un grupo de 166 chonos, sin previo aviso y sin mediar misión ni viaje jesuita a sus islas, llegó al fuerte de Calbuco manifestando su deseo de vivir entre españoles. Primero llegaron treinta familias y se les instaló en una isla cercana, Guar, que la autoridad reservó para su exclusivo asentamiento. Más tarde se contaban 500 indios asentados en tres islas del mar interior de Chiloé. Los jesuitas obtuvieron la tutela sobre ellos, convirtiendo a la primera isla en una reducción que fue declarada como misión bajo el título de San Felipe de Guar, según cédula de 1717. Como neófitos, no quedaron sujetos a encomienda ni tributación, aunque se intentó hacerlos vivir a la manera española y transformarlos en sedentarios y agricultores. No obstante, no se vieron los frutos esperados. Ya antes de 1720, los chonos habían ido abandonando la misión, regresando a sus antiguas islas o instalándose en otras, como Quiapu, Apiao, Chaulinec y otras adyacentes a Quinchao. Pocos quedaron en Guar. Urbina, X. (2013a).

89 Williams, G. (2002). El mejor botín de todos los océanos. La captura de la nao de China en el siglo XVIII. México: Editorial Océano; Vázquez de Acuña, I. (2003). La incursión del Comodoro George Anson (1740-1744) y sus consecuencias en Chile, Boletín de la Academia Chilena de la Historia, 112, 215-247; Benavente, M. (1983). Más sobre la expedición marítima del comodoro inglés Anson a las costas sudamericanas y la flota española del almirante Pizarro. Boletín de la Academia Chilena de la Historia, 94, 285-289; Canseco, A. (1982). La escuadra de Jorge Anson y José Pizarro en el Atlántico austral. Historia maritima argentina (T. III, cap. XIV, pp. 349-375). Buenos Aires: Editorial Cuántica.

90 Véase AA.VV. (2012). Cuatro relatos para un naufragio. La fragata Wager en el golfo de Penas. Santiago: Ediciones Septiembre. 
tierras que los españoles reconocían como de huilles, payos, cau cau o gaviotas, de indios gigantes, o del cacique Talcapillán; tierras de Ayana, Allauta, Pucaqui y otras, fue entendida como algo natural, porque los chonos o guaiguenes [...] han estado yendo y viniendo toda la vida y todo este año yendo $y$ viniendo, $y$ proseguirán yendo y viniendo ${ }^{91}$, porque, aunque las tierras de Guayaneco no son suyas [de Olleta], son confinantes a las suyas, y siempre se han comunicado estos indios con aquellos ${ }^{92}$.

91 Pedro García, rector del colegio jesuita de Castro, al gobernador de Chiloé Martínez de Tineo, Chacao, 7 de mayo de 1744. La carta está contenida en el expediente sobre un conflicto entre el gobernador de Chiloé y el colegio jesuita de Castro, de ese mismo año, en el Archivo del Arzobispado de Santiago, Chile, Varios, f. 18. Este expediente tiene una extensión de 52 fojas con vuelta, y está en papel sellado. Fue levantado por el gobernador de Chiloé, Juan Victorino Martínez de Tineo en 1744, para hacer averiguaciones sobre el despacho de una embarcación tripulada por caucahués, que los jesuitas de Chiloé hicieron al sitio del naufragio de la fragata inglesa Wager, en el archipiélago de Guayaneco. Este despacho contravenía la orden dada por el gobernador para que nadie fuese al sitio del naufragio a coger el metal del barco, y por eso se hicieron las averiguaciones. Este documento no tiene clasificación en el Archivo del Arzobispado de Santiago. Se conoce porque el antiguo encargado del archivo se lo facilitó al padre Gabriel Guarda O.S.B., Presidente de la Comisión de Bienes Culturales de la Iglesia Católica, para que conociera su valor, dada la rareza de su existencia. Después de su valoración se hizo una copia del documento, con autorización del Archivo, al cual se regresó. El Dr. Rodrigo Moreno, colaborador del P. Guarda, utilizó dicha copia hace diez años en su tesis doctoral sobre los jesuitas en Chiloé, y la compartió posteriormente conmigo. Dado que no tenía clasificación dicho documento, y porque ahora se desconoce la nueva, en adelante nos referiremos a éste simplemente como "Expediente AAS".

92 Ibidem, f. 20. Antes, el 28 de marzo de 1742, cuando los náufragos llevaban 10 meses en Guayaneco, el gobernador de Chiloé, Francisco Gutiérrez de Espejo, se enteró por carta del presidente de Chile, Manso de Velasco, de la noticia de los ataques de Anson en Paita y en el Pacífico. El presidente ordenó que la provincia estuviera alerta, que se retirasen los ganados al interior de las islas de tal manera que los extranjeros no pudiesen encontrar alimento fácil, y que inmediatamente se despachasen indigenas chonos a reconocer las islas del sur hasta el estrecho de Magallanes (El gobernador de Chiloé Francisco Gutiérrez de Espejo al presidente de Chile, Manso de Velasco, Chacao, 25 de junio de 1742. AGI, Chile, 98). No menciona Espejo que haya enviado al reconocimiento que mandaba Manso, y Olleta llegó al naufragio en febrero de 1742, antes de llegara a Chiloé dicha orden de reconocer las islas al sur. Por lo tanto, puede desprenderse que Olleta fue por su cuenta, ya que los chonos se desplazaban regularmente en los archipiélagos, o que los gobernadores de Chiloé mantenían un patrullaje habitual hacia el sur a cargo de chonos amistados. Pero también puede ser que la orden del presidente haya llegado antes a Chiloé, en febrero, por la vía de Valdivia, que aunque
Entonces, en junio de 1742, se difundió por todo Chiloé la novedad del barco inglés naufragado, de nación con la que se estaba en guerra, en una isla de las más australes de Chiloé, con descripción de su tamaño, artillería y carga. Había encallado muy cerca de la playa y parte de su materialidad y especies que transportaba como nave de abastecimiento deberían estar en el campamento de los náufragos ${ }^{93}$. Los ingleses, además, revelaron a los españoles de Chiloé que al lugar del naufragio habían llegado unos indígenas que no sabían de la existencia de los españoles: los caucahues. Diferenciaban a aquellos que reunieron el hierro en el campamento, de otros que no le dieron importancia alguna, y que a Byron le pareció no habían visto nunca a un europeo ${ }^{94}$. Interesaban, por lo tanto, dos asuntos: conseguir restos del naufragio, sobre todo el hierro, tan escaso en Chiloé, y conocer, para evangelizar, a los indígenas "nuevos". Sobre los restos, el gobernador buscó obtener la artillería; los jesuitas querían las anclas; y la población en general, jesuitas, españoles e indígenas, el metal en cualquier forma, para fundirlo ${ }^{95}$.

Para ello se hicieron algunos viajes. El primero de ellos fue la expedición enviada por el gobernador de Chiloé, Francisco Gutiérrez de Espejo, a fines de 1742, quien despachó al naufragio dos piraguas a recoger hierro ${ }^{96}$. No hay mención alguna de la expedición, sino

igualmente marítima, era más rápida que desde Chile.

93 El capitán Cheap habría señalado que el barco había quedado entero con toda la artillería y anclas. Amat y Junient, M. [1760] (1924-1928), 60, p. 417.

94 Alexander Campbell dice que los primeros indígenas que se acercaron al naufragio se diferenciaban de un segundo grupo, que acumuló hierro and others materials wich we knew they had taken from the wreck of our unfortunate ship. As the indians hereabouts know nothing of iron, and set no value on it, we conjectured that those who had been here traded with the spaniards. Campbell, A. (1747). The sequel to Bulkeley and Cummins's voyage to the South-Seas: or the adventures of capt. Cheap... Londres: W. Owen, p. 51. Véase Carabias, D. (2009). Encuentro de dos mundos. Naufragio del H.M.S. Wager en la Patagonia. Arqueología histórica en el golfo de Penas: investigación de los restos de la fragata Wager (1741), archipiélago de Guayaneco, XI región de Aysén. Santiago: Productora Gráfica MC4, Consejo Nacional de la Cultura y las Artes.

95 Urbina, X. (2013b). Expediciones desde Chiloé para recoger el metal del barco inglés Wager de la flota de George Anson, naufragado en el Pacífico austral en 1741: el conflicto del hierro en Chiloé. Manuscrito Inédito.

96 Martínez de Tineo al cura vicario y foráneo de Chiloé, Pérez de Aguilar, Chacao, 26 de mayo de 1744, Expediente 
que sólo sabemos que el grupo volvió con especies ${ }^{97} \mathrm{y}$ con una idea exacta de la situación de los 28 cañones de bronce y hierro del barco, además de anclas, y metal en general, más jarcias y otras especies que interesaban en Chiloé, que debido a su lejanía y pobreza carecía de lo más mínimo.

A continuación de la anterior, hubo una primera expedición jesuita hacia el naufragio, que tuvo como objetivo la extracción de metal. Fue entre marzo y mayo de $1743^{98}$, enviada por Pedro García, rector del colegio jesuita de Castro, quien habilitó y despachó cuatro piraguas al mando del jesuita Pedro Flores, y en este viaje iba el indígena Mateo Tacull, indio guaiguen, alias chono, habitador de la isla de Chaulinec, quien en la práctica consiguió el hierro que Flores luego condujo a Chiloé. El hierro llevado por jesuitas a Chiloé generó un enfrentamiento entre la orden y el recién llegado nuevo gobernador de Chiloé, Martínez de Tineo, quien quería cautelar el derecho que el rey tenía sobre las especies del naufragio. Hubo otro, fallido, despacho jesuita a recuperar especies del naufragio, en 1743 , después de mayo. Esta vez, los jesuitas habilitaron una piragua al mando de Mateo Tacull, pero que, por no considerarse suficientemente compensados, no pasó mas allá de las islas Guaitecas ${ }^{99}$. ¿Hubo viajes de particulares a buscar hierro? El jesuita García dijo que sí, que habían ido casi todos los vecinos de esta provincia, pues raro será el que no haya solicitado, animado, rogado y aviado a dichos indios a fin de que les vayan a traer fierro, pagándoselo muchos

AAS, f. 27v. A este despacho debe referirse Campbell cuando, relatando su estadía en Chiloé y entrevista con el gobernador, dice que éste envió canoas al sitio del naufragio. Campbell, A. (1747), p. 76. También, en p. 74 dice The governor examined the indians that brought us, and made him go with his canoes and some soldiers to Wager-island, to work upon the wreck of our ship.

97 Las cajas reales de Chiloé informaron que con fecha de 6 de abril de 1743, el gobernador Gutiérrez de Espejo les entregó 21 quintales de fierro, en 79 piezas grandes y pequeñas, provenientes del naufragio. "Relación de cargo y data del fierro que hemos recibido en esta real caja de nuestro cargo perteneciente a S. Majestad del navío naufragado del enemigo inglés en 3 partidas según y como consta en los libros reales de nuestro cargo", Chacao, 12 de abril de 1745. AN, CG, Vol. 379, fjs. 408 y sgtes.

98 El padre rector dice que "llegó el año pasado por este mismo mes”. Pedro García, rector del colegio jesuita de Castro a Martínez de Tineo, gobernador de Chiloé, Chacao, 7 de mayo de 1744, Expediente AAS, f. 19v.

99 Declaración de Mateo Tacull, Chacao, el 12 de mayo de 1744, Expediente AAS, f. 26v. adelantado, ya con ciento, ya con doscientos y más pesos. Y no han faltado algunos que con la misma sinceridad que yo les hayan prestado piraguas ${ }^{100}$. Pero apunta que sólo la minoría consiguió hierro, porque los indígenas no cumplían con el encargo.

Desde una fecha imprecisa a finales de 1743 y hasta febrero de 1744, se desarrolló la expedición al mando del sargento mayor de la provincia, Mateo Abraham Evrard, a recoger los cañones de la Wager ${ }^{101}$. El grupo estaba conformado por 11 piraguas construidas ex profeso, también piragüillas (de indígenas) y un total de 160 personas, con bastimentos para 6 meses. El grupo navegó el golfo de Corcovado, canal Moraleda, cruzó el istmo de Ofqui con todas sus piraguas, navegó el golfo de Penas, y estuvo en la faena extractiva en una isla de las islas de Guayaneco. Regresó con 7 piraguas, dejando 4 de ellas en la parte sur del Desecho de Ofqui, probablemente para asistir a una siguiente expedición ${ }^{102}$.

En Guayaneco, dice el documento siete años posterior, el grupo interactuó pacíficamente con los indígenas locales ${ }^{103}$, y Abraham Evrard hizo una nueva toma de posesión y recibió el juramento al rey de parte de los indígenas ${ }^{104}$. Estos parlamentos se hicieron cuando entró a la ensenada de los caucaos, y que esto fue después de sacada la artillería. La nueva toma de posesión y el juramento de fidelidad podía ser reiterativo, pero era un acto necesario, para que ninguna nación extranjera pudiese alegar posesión, y para intentar

100 Pedro García, rector del colegio jesuita de Castro, al gobernador Martínez de Tineo, Chacao, 7 de mayo de 1744, Expediente AAS, f. 19.

101 La expedición precedente, de fines de 1742, alrededor de 19 meses después de la llegada de los náufragos ingleses, explica la aparente tardanza de la salida de la de Mateo Abraham Evrard, un año y medio más tarde de saberse la noticia del naufragio. Este grupo de avanzada pudo haber descrito con detalle la situación del navío, y en consecuencia suscitado una preparación acorde con la envergadura de la maniobra: existían en el agua al menos 28 cañones, anclas, aparejos y otras piezas grandes. Además, según los intereses de las autoridades de Chiloé y del presidente de Chile, debía procederse con el mayor cuidado para evitar que el hierro de Guayaneco cayera en manos directas de particulares, en vez de las de la real hacienda.

102 Urbina, X. (2013b).

103 Amat y Junient, M. [1760] (1928), 60, p. 418.

104 Juramento de ser leales vasallos a Su Majestad Católica, y que por ningún caso saldrán de la corona de Castilla y León bajo de cuyo amparo y patrocinio están. El gobernador de Chiloé, Antonio Narciso de Santa María al presidente Ortíz de Rozas, Chacao, 30 de enero de 1750, AGI, Chile, 98. 
asegurar que los indígenas no se aliaran o vincularan con extranjeros. No se menciona en ningún momento que haya viajado con él jesuita o religioso alguno, pero es factible suponer que fue con ellos el padre Pedro Flores, quien ya había ido a Guayaneco entre marzo y mayo de 1743. Abraham Evrard condujo a Chiloé 14 de los 28 cañones del barco, más un anclote, un yunque, $y$ otras piezas ${ }^{105}$.

Hubo un tercer despacho jesuita, entre marzo mayo de 1744. Se trató de una piragua habilitada por el padre Pedro Flores, superior de la misión de Chequián, isla de Quinchao, ejecutada por guaiguenes, neófitos recién atraídos y trasladados por el padre Pedro Flores un año antes, y que, además habían regresado sólo hace algunos días de la expedición hecha por Abraham Evrard $^{106}$. Ellos rescataron un yunque y otras piezas menores de hierro, que fueron decomisadas por el gobernador de Chiloé ${ }^{107}$.

El naufragio, por tanto reabrió la ruta de Ofqui, que fue transitada en varias ocasiones y en ambos sentidos en los años siguientes, por expediciones oficiales españolas, y de particulares, más viajes indígenas y de misioneros. No sólo reabrió esta antigua ruta (cuyo último tránsito español había sido el de Vea, en 1676, 66 años antes), sino que también el naufragio volvió a relacionar a los españoles con los indígenas caucaus, y otros grupos de los que la documentación sólo da el nombre: huillis, taijatafes y la nación calén.

Los jesuitas se interesaron por visitar a los caucahues, referidos por los ingleses sobrevivientes. Se vio en ella una nueva cristiandad por atender ${ }^{108}$. Eso sí, y con la antigua experiencia de comienzos del siglo anterior, en que la evangelización de los indígenas no daba resultado ni en la frustrada misión de Nahuelhuapi ${ }^{109}$, ni aún en las islas Guaitecas, cercanas a Chiloé, porque los indígenas no acudían a la visita anual de los padres, ni ellos podían controlar a su feligresía, la modalidad de

105 "Relación de cargo y data del fierro que hemos recibido en esta real caja de nuestro cargo perteneciente a S. Majestad del navío naufragado del enemigo inglés en 3 partidas según y como consta en los libros reales de nuestro cargo", Chacao, 12 de abril de 1745, AN, CG, Vol. 379, fjs. 408 y sgtes.

106 Pedro García a Martínez de Tineo, Chacao, 7 de mayo de 1744, Expediente AAS, f. 18v.

107 Pedro Téllez, Chaulinec, 27 de mayo de 1744, Expediente AAS, f. $44 \mathrm{v}$.

108 Casanueva, F. (1982), p. 22.

109 Urbina, X. (2008). La frustrada misión estratégica de Nahuelhuapi, un punto en la inmensidad de la Patagonia. Magallania, 36(1), 5-30. evangelización de estas nuevas etnias fue mediante el traslado de personas a Chiloé. Desde un comienzo se pensó en ello, porque civilizarlos en su dispersión era imposible, y reducirlos en algún punto de la inmensidad de la Patagonia costera era impracticable. Los jesuitas hicieron varios viajes hacia el sur, más allá del istmo de Ofqui, por el golfo de Penas y el canal Messier, para ir a recoger las que llamaron preciosas margaritas. Sin mediar discusión ni autorización respectiva, se puso en práctica el traslado a Chiloé desde 1743. Aunque se hablaba de multitud de almas, en la práctica los jesuitas pudieron relacionarse con grupos indígenas muy poco numerosos. Se les consideraba dóciles, porque pudieron concretarse traslados, y por lo mismo, no se refiere que se haya aplicado la fuerza física; más bien se ejecutó una política de agasajos y regalos. Desde el punto de vista español, y siendo el objetivo la evangelización y civilización, la desnaturalización de estos neófitos se veía como algo natural y lógico para tal objetivo. Por otro lado, lo que se pretendía con ello era evitar que estos nuevos indígenas se aliaran con enemigos ingleses y les prestaran auxilio para apoderarse del reino de Chile, sobre todo considerando que fueron los mismos ingleses quienes advirtieron de su existencia. Dejar el territorio despoblado era, por lo tanto, dejarlos sin apoyo logístico vital en el caso de recalar en aquellas costas, como había quedado demostrado con el naufragio de la Wager.

De esta forma, en 1743 el jesuita Pedro Flores hizo que un grupo de chonos de los estantes - al menos temporalmente - en Chequián lo llevara al sitio del naufragio, desde donde trajo consigo un grupo a los que en la documentación se les llama en ocasiones chonos, también guaigüenes y en otras caucahués, y los asentó en Chaulinec. Tenemos información de otra correría misional, sólo referida por un documento jesuita, que dice que en 1760 hubo una nueva expedición en busca de indígenas en Guayaneco, al parecer sólo ejecutada por caucahués estantes en la isla Cailín, quienes lograron conducir hasta Chiloé a trece individuos que se identificaron como de "naciones" distintas, denominadas como taijataf y calenche $e^{110}$. Cuatro años más, en 1764, se fundó formalmente la misión de Cailín, en el mar interior de Chiloé, para atender a los grupos australes. La petición, según el plan del jesuita Juan Nepomuceno Walter, proponía que desde

110 Informe de Nepomuceno Walter, Santiago, 9 de enero de 1764, AGI, Chile, 240. 
Cailin se hicieran entradas con los mismos caucahués al estrecho de Magallanes, para reducir a nuevas naciones, para lo que también se pidió un sínodo adicional de cien pesos por cada año que se hiciesen entradas ${ }^{111}$. La primera entrada fue en 1765, en que José García fue al sur de las islas Guaitecas, y que escribió un diario, pero se desconoce y no hay mas información ${ }^{112}$. En el verano de 1766-1767 se llevó a cabo la segunda de estas salidas, también por el jesuita García, compuesta por 5 españoles y 34 caucahués, y que regresó con 15 personas de las naciones huilli, taijataf y calenche $e^{113}$. Esta expedición, que dejó un pormenorizado diario de viaje, cruzó el istmo de Ofqui y avanzó y recorrió las islas al sur del golfo de San Esteban. Además dejó un mapa, con especificación de la ruta seguida, $e$ importante información etnográfica y geográfica que la sensibilidad del jesuita quiso consignar, a diferencia de otros viajes de la época hacia el canal Messier, por la misma ruta. Al verano siguiente, el jesuita Juan Vicuña cruzó Ofqui para continuar lo iniciado por García, pero al regreso naufragó y murió. No conocemos de este viaje más que por las referencias que dio Pedro Mansilla, teniente de una expedición militar paralela, que se encontró con él precisamente en Ofqui.

Luego de la expulsión de los jesuitas, los franciscanos retomaron los viajes desde la misión de Cailín. En 1773 se realizó la expedición misional del franciscanos Felipe Sánchez, al parecer la primera, que congregó en Chiloé a 196 indígenas canoeros australes ${ }^{114}$, mientras que en su expedición misional del verano de 1778-1779 los franciscanos Benito Marín y Julián Real partieron desde Castro, en tres piraguas - una grande y dos pequeñas -, con prácticos de los sitios que intentaban reconocer, y del idioma de los gentiles que iban a buscar, y piloto que con seguridad les condujese a aquellas remotas islas.

111 Idem.

112 Hanisch, W. (1982), p. 68.

113 García, P. [1766-1767]. Diario del viaje y navegación hecho por el padre Joseph García de la Compañía de Jesús desde su misión de Kailín, en Chiloé, hacia el sur. Año 1766. En Von Murr, Gottlieb (1811). Nachrichten von verschiedenen Landern des spanischen Amerika (pp. 506-598). Halle: Verlegt bev Joh. Christian Hendel. El Diario está tanto en castellano como en alemán e incluye el famoso mapa hecho por el padre García. Von Murr no dice de dónde obtuvo este diario.

114 Urbina, R. (1991). Las misiones franciscanas de Chiloé a fines del siglo XVIII: 1771-1800. Valparaíso: Ediciones Universitarias de Valparaíso, p. 86.
Iban a los archipiélagos de Guaitecas y Guayaneco. En el avance, y de la misma manera que Pedro García, el diario va consignando topónimos, la mayoría de ellos indígenas. Cruzaron Ofqui navegando la laguna San Rafael, salieron a la isla de Guayaneco, donde reconocieron haber sido el naufragio 27 años antes. Se aproximaron a la boca del canal Messier, nombrando la isla la Campana, y el canal de Fallos, desde donde deshicieron el camino conduciendo a 11 individuos más ${ }^{115}$. Al año siguiente, en 1779-1780, fray Francisco Menéndez y fray Ignacio Vargas continuaron la travesía hacia el sur, en la misma piragua que Marín y Real, la Patrocinio, que también subieron por la escalera del Desecho de Ofqui, salieron al golfo de San Esteban y sin avanzar mas hacia el sur que los frailes que inmediatamente les precedieron, sino a la altura de la isla Ayantau, que debe ser cercana a la tierra firme, regresaron a Chiloé con 32 indígenas que encontraron en esa área ${ }^{116}$. Aun cuando en 1750 , y luego en 1763 , 1767, 68, 69 y 70 se hicieron viajes bordeando la costa occidental del archipiélago de los Chonos hacia el puerto donde estuvo refugiado otro barco de la flota de Anson, el Anna, en 1741, en la península de Taitao, las expediciones misionales continuaron realizándose por el gran canal interior, el Moradela. Ésto se explica no sólo por el peligro que suponía vencer el cabo Tres Montes para salir el golfo de Penas, área de los caucahués, sino porque las expediciones "por fuera" no encontraron indígenas, o eran tan pocos que no hicieron valer la pena aventurarse por aquellas costas tan expuestas como despobladas.

115 "Extracto de la expedición que los padres Fr. Benito Marin y Fr. Julián Real, misioneros del colegio de Ocopa y destinados a las misiones del archipiélago de Chiloé, hicieron a últimos del año de 1778 y principios del de 1779 a los archipiélagos de Guaitecas y Guayaneco al sur de aquella provincia en solicitud de los indios gentiles...". En González de Agüeros, P. (1791). Descripción historial de la provincia y archipiélago de Chiloé en el reino de Chile, y obispado de la Concepción (pp. 217-242). Madrid: Imprenta de Don Benito Cano. Quizá de aquí la copió Vidal Gormaz, porque no dice de dónde, para: ANH, VG, Vol. 7, pza. 8 (1), fjs. 389-420.

116 Segunda expedición hecha a los referidos archipiélagos de Guaitecas y Guayaneco por los religiosos misioneros padres Fray Francisco Menéndez y el padre Fray Ignacio Vargas, en solicitud de la reducción de los gentiles a fines del año 1779 y principios del de 1780, según consta de la carta escrita al padre Fray Julián Real por el citado padre Fr. Francisco Menéndez, que es como sigue, en González de Agüeros, P. (1791), pp. 243-250. Al igual que el documento de la cita anterior, de este libro de González de Agüeros lo debe haber copiado Vidal Gormaz para: ANH, VG, Vol. 7, pza. 8 (2), fjs. $421-427$. 
No hay registros de más de estos viajes misionales. Las expediciones con fines económicos (obtener hierro y otros elementos), de 1742, 1743 y 1744 no tuvieron como objetivo hacer averiguaciones de Césares, tanto españoles como extranjeros, porque la llegada de los cuatro náufragos a Chiloé después de un año en las costas patagónicas había demostrado la hostilidad de aquellos parajes para europeos - incluso el virrey del Perú es tajante en decir a España, en 1747. que en este Mar del Sur no hay corsarios algunos ${ }^{117}$ -, y el que un cacique chono los haya encontrado, demostraba, a su vez, la efectividad del patrullaje en manos de indígenas.

\section{Expediciones de búsqueda de establecimientos} de ingleses, 1749-1792.

En 1745, desde Madrid se ordenó al virrey del Perú que informase si había corsarios -ingleses- en el Mar del Sur ${ }^{118}$, procurando la recalada de las naves españolas en el archipiélago de Juan Fernández. En octubre de 1747 salió desde El Ferrol una flotilla compuesta por dos navíos para patrullar la costa pacífica sur, que pasó al Callao, desde donde se desplazó a Concepción, ida y vuelta, y dado que confirmó el no haber peligro de extranjeros en las costas, el virrey anunciaba su regreso a España para octubre de $1749^{119}$. Sin embargo, en mayo de 1749 se ordenó al virrey el reconocimiento y poblamiento de las islas de Juan Fernández y de Inche en el archipiélago de los Chonos ${ }^{120}$. Se decía que era una isla, aunque en la realidad Inche no lo es, sino que se referían a la isla de Tenquehuén, que está inmediata a la península de Taitao.

La alarma y actividad en los mares australes se explica porque en 1749 llegó a la corte de Madrid la información que en Inglaterra se estaba preparando una fragata de 14 cañones para tomar posesiones en el Pacífico sur ${ }^{121}$. Unido a ello, en

117 El virrey Manso al marqués de la Ensenada, Lima, 29 de enero de 1747. AGI, Lima, 643.

118 Idem.

119 Del virrey Manso al marqués de la Ensenada, Lima, 12 de junio de 1749. AGI, Lima, 643.

120 S.M., Aranjuez, (blanco) de mayo de 1749. AGI, Chile, 433.

121 El rey ha recibido segura noticia de que en Inglaterra se estaba habilitando una fragata con 14 cañones aunque capaz de montar muchos más, y que se destina a pasar a ese Mar del Sur a hacer varios reconocimientos de las
1748 se publicó en Londres la versión autorizada del viaje de George Anson, escrita por el capellán de uno de los barcos, Richard Walter ${ }^{122}$. En él se describían las acciones de la flota en el Pacífico y los ataques a los puertos españoles, pero también quedaba en evidencia la vulnerabilidad de varios lugares del reino de Chile, por la estadía de uno de sus navíos, el pingüe Anna, en "la isla" de Inche, y por el refugio seguro conseguido en las islas de Juan Fernández, además del naufragio de la Wager. Anson, de acuerdo a su experiencia, recomendaba instalar algún establecimiento en esos mares, con el fin de practicar el comercio.

Como consecuencia de ello, el rey puso en alerta al virrey del Perú, el 7 de mayo de 1749, y ese mismo año mandó a habilitar una fragata del Callao, la Esperanza, y a preparar otras dos, de particulares comerciantes, para hacer un fuerte y poblar con civiles la isla más grande del archipiélago de Juan Fernández (isla más a tierra, actual Robinson Crusoe), y un fuerte de madera en la isla de Inche, para que cualquiera embarcación que a él arribare, halle gente nuestra y por ella tomada solemnemente la posesión que tiene su majestad conforme al legítimo derecho que le constituye señor natural de todas las dichas islas ${ }^{123}$, además de reconocer

islas de él. Convida a aquella nación y corte la práctica de esta idea, la noticia que el almirante Anson da en la obra y relación que ha impreso de su viaje desde su salida de Inglaterra hasta su vuelta del continente e islas de esos mares y las ventajas que se promete de que por su nación se ocupase alguna de ellas. El marqués de la Ensenada, al virrey del Perú, Aranjuez, 7 de mayo de 1749. AGI, Chile, 433.

122 Es de 1748 y se llama A voyage round the world, in the years MDCCXL, I, II, III, IV, by George Anson, esq., commander in chief of a squadron of His Majesty's ships, sent upon an expedition to the South-Seas / compiled from papers and others materials of the Right Honourable George Lord Anson, and published under the direction by Richard Walter. London: Printed for the author, by John and Paul Knapton. La primera traducción al español es de 1833, pero antes hubo otra, hecha entre 1748 y 1752 (de José Antonio de Aguirre, con el título Vuelta al mundo dada por Jorge Anson en los años 1740, 1741, 1743 y 1744) que no llegó a ser publicada. Véase Torres, M. (2004). Un best seller del siglo XVIII: el viaje de George Anson alrededor del mundo. Biblio 3W, Revista Bibliográfica de Geografía y Ciencias Sociales (serie documental de Geo Crítica), Vol. 9, 531 Disponible en http://www.ub.edu/geocrit/b3w-531.htm

123 Autos sobre la población de la isla de Inche o Tenquehuén en la provincia de Chiloé, por don Antonio Narciso de Santa María, Chacao, 17 de marzo de 1750, AGI, Lima, 643. 
todo el archipiélago de los Chonos $^{124}$ durante tres meses (mediados de 1750) en busca de la fragata inglesa, que se suponía haría su travesía desde Inglaterra en el verano de 1749-1750 ${ }^{125}$. La orden llegó al gobernador de Chile en los primeros días de enero de 1750 y a fines de enero al de Chiloé, a quien se le envió en navio del comercio, de forma directa, el 11 de diciembre de 1749. En ella le ordenaba que esperase a la fragata Esperanza, previniéndole ponga una piragua en puerto inglés [península de Lacuy, en la isla grande de Chiloé] y otra en la isla de Guaiteca, a donde van los chonos todos los años, y está en la latitud de 45 grados 25 minutos sur, para que luego que se aviste la Esperanza y haga sus señales se unan con ella y pueda el comandante por este medio pedirle los prácticos y auxilios que necesitare y que estén a sus órdenes para acompañarle al referido archipiélago si lo juzgare necesario para el reconocimiento de sus entradas y fondeaderos ${ }^{126}$. En cumplimiento de la orden, desde Chiloé, su gobernador Antonio de Santa María envió las dos piraguas, primero al puerto inglés y luego al archipiélago de las Guaitecas, donde desde el 6 de febrero de 1750 estuvo el alférez Martín López $^{127}$ a la espera de la Esperanza, para que se formase un exacto plano de la situación, costas y distancias, de sus habitadores, genio y costumbres, de las producciones del terreno y de la abundancia o escasez de peces, y de todo lo demás que podía contribuir al perfecto conocimiento que se desea, lo que debía hacerse con esas embarcaciones de la tierra, porque en el estrecho de los canales podría peligrar la fragata, decía el presidente de Chile $e^{128}$. López quedó con orden de pasar desde las Guaitecas al archipiélago de los Chonos, el 20 de marzo, aun cuando

124 Del marqués de la Ensenada al conde de Superunda, Aranjuez, 7 de mayo de 1749. AGI, Chile, 433. La recibió el virrey el 27 de octubre de ese año.

125 Véase a Guarda, G. (1990). Flandes Indiano. Las fortificaciones del reino de Chile. Santiago: Universidad Católica de Chile, pp. 18-29; Hanisch, W. (1982), pp. 59-65; Olguín, C. (1971). Instituciones políticas administrativas de Chiloé en el siglo XVIII. Santiago: Editorial Jurídica de Chile, pp. 31-33; Martinic, M. (2005), p. 61.

126 El virrey, conde de Superunda, al marqués de la Ensenada, Lima, 20 de enero de 1750. AGI, Lima, 643.

127 Representación de Ortíz de Rozas al Rey, Santiago, 4 de mayo de 1750, con testimonio de autos obrados sobre las providencias de la nueva población del puerto de Inche o Tenqueguen en el archipiélago de los Chonos. AGI, Chile, 433. También AGI, Lima, 643.

128 Idem. no llegase la fragata Esperanza, para aprovechar lo último del verano, y permanecer en "la isla" de Inche con 6 soldados españoles y 8 indios ${ }^{129}$. Santa María, mientras tanto, hizo averiguaciones sobre Inche entre los hombres más prácticos de esta provincia, e informó que en realidad no era una isla, sino que era un lugar en la isla de Tenquehuén, y que por su lejanía, por su incapacidad para cultivos, por distar 20 leguas de la tierra firme que es sólo cordilleras nevadas, y por la dificultad de acceder a ella debido a bajíos, golfos y corrientes, no era factible que los ingleses consiguieran acceso a Chiloé, o a las pampas patagónicas, asentándose en ella. Por las mismas razones, tampoco aconseja que la pueblen los españoles de Chiloé, a menos que desde Lima se esté dispuesto a mantenerlos del todo. Destaca la fidelidad a España de los indígenas de esos archipiélagos, y la conveniencia de prestar atención a Chiloé, fortificándolo, en vez de la isla de Tenquehuén ${ }^{130}$. La Esperanza salió de Concepción rumbo a Chiloé el 10 de marzo de $1750^{131}$. Al llegar al puerto del inglés, le informaron que se habían avistado velas de 3 navíos en conserva rumbo al norte, por lo que se pensó que se trataba de la fragata inglesa que iba rumbo a Juan Fernández. Por entonces, ya se habían conducido a esa isla los nuevos pobladores, con su gobernador, y se estaba iniciado la ocupación española, razón por la cual la Esperanza se devolvió a Juan Fernández, sin hacer el reconocimiento del archipiélago de los Chonos $^{132}$. Las velas, por cierto, no eran de la fragata inglesa, que nunca estuvo en el Pacífico y no pasó de ser una errada o malintencionada información.

Durante ese invierno en que la Esperanza no pudo pasar al archipiélago de los Chonos y a Inche a cumplir su objetivo, el gobernador Santa María envió a ejecutarlo. Encomendó el reconocimiento a su ayudante, Manuel Brizuela, que lo hizo entre el 21 de marzo y el 11 de junio de 1750 , quien se juntó en la isla Cailín con las personas bajo el mando de López. Tomaron posesión, en acto solemne, de la isla de Tenquehuen, y por no ofrecer ella terreno capaz y habitable, se levantó una casa en la isla inmediata de

129 Idem.

130 Antonio Narciso de Santa María al virrey del Perú, Chacao, 7 de febrero de 1750. AGI, Lima, 643.

131 Certificación dada en Concepción, 16 de marzo de 1750. AGI, Chile, 433.

132 Del virrey del Perú, conde de Superunda, al marqués de la Ensenada, Lima, 18 de septiembre de 1750. AGI, Chile, 188. 
Caychilu, que está a la vista del puerto donde ancló el pingüe inglés de la escuadra del almirante Anson. En ella, por falta de bastimentos para todo el grupo, dejó sólo a un soldado y al cacique de la reducción de Abtao, para que pasasen alli el invierno ${ }^{133}$. En su diario, Brizuela ${ }^{134}$ argumenta sobre la imposibilidad de mantener población en esos parajes, y entrega 3 planos de la isla ${ }^{135}$, que sin embargo, no consignan latitudes. Por esta razón, el gobernador de Chiloé despachó a Mateo Abraham Evrard ${ }^{136}$, quien salió el 5 de octubre y regresó a Chiloé en noviembre de 1750 , con 3 piraguas y 12 hombres de la tropa arreglada, varios caciques de Calbuco e indios chonos, 42 hombres en total, con orden de levantar un fuerte de madera en la isla de Caychilu, que se llamó San Fernando de Tenquehuén, y dejar en él su alférez, 6 soldados, dos caciques de Calbuco y un chono práctico por 6 meses para mantener la vigilancia ${ }^{137}$. Hizo un plano general entre Chiloé y el estrecho de Magallanes ${ }^{138}$, que no ha llegado a nosotros. El fuerte fue de corta existencia -sólo 18 meses-, porque de orden del virrey se hizo desmantelar ${ }^{139}$.

Brizuela hizo recorrido entre Chiloé y la isla Tenquehuén, es decir, tocando la isla Guafo y siguiendo hacia el sur, por la costa patagónica pacífica. Es quizá la primera vez, después de los dos viajes de mediados del siglo XVI hacia el estrecho de Magallanes, que se navega desde Chiloé al sur por mar afuera y no por

133 El presidente Ortíz de Rozas al Rey, Santiago, 24 de diciembre de 1750. AGI, Chile, 433

134 Hay información del viaje del ayudante Manuel Brizuela en AGI, Chile, 433 y AGI, Lima, 643, También en BN, MM, T. 270, fjs. 633-667, y T. 187, fjs. 102-187, y en ANH, CG. Vol. 385, fjs. 177-178. El Diario fue publicado: Medina, J. (1916). Primer viaje de exploración a la isla de Tenqueguen, Diario y derrotero de don Manuel Brizuela. Revista Chilena de Historia y Geografía, T. XIX, 23, pp. 5-29, y nuevamente publicado en Medina, J. (1962). Viajes relativos a Chile. Santiago: Fondo Histórico y Bibliográfico José Toribio Medina, Tomo I, pp. 145-165.

135 AGI, Mapas y Planos, Perú y Chile, 34, 34BIS y 34 TER.

136 El viaje está descrito en una carta del gobernador de Chiloé, Antonio Narciso de Santa María al virrey del Perú, fechada en Chacao, a 24 de octubre de 1750. AGI, Lima, 643. Hay alguna información relativa en AGI, Chile, 433. Está mencionado en Amat y Junient, M. [1760] (1924-1928), 60, 415-418; 61, 324; 62, 308-309.

137 El presidente Ortíz de Rozas al Rey, Santiago, 24 de diciembre de 1750. AGI, Chile, 433

138 El virrey conde de Superunda al marqués de la Ensenada, Lima, 20 de diciembre de 1750. AGI, Lima, 643.

139 Silva y Molina, A. (1899). ANH, FV, Vol. 141, fjs. 188v-189. el canal Moraleda. La noticia de Anson daba puntual ubicación del paraje donde había estado el Anna, al que Brizuela llegó guiado por Domingo Guenupal, principal práctico de Tenquehuén ${ }^{140}$. En su diario se centra en las descripción de las islas Tenquehuén y Caychilu, casi sin puertos capaces siquiera de piraguas, abundancia de maderas y tierra no apta para el cultivo. No tenemos más noticia del viaje siguiente, el de Abraham Evrard, en 1750, que la que muy concisa ya referida. En la Historia Geographica se confunde el viaje de 1743 (por el canal Moraleda e istmo de Ofqui) con el de 1750, de cara al océano Pacífico, y es difícil distinguir a cada uno. Lo más probable es que sólo se refiera a este viaje de 1750 cuando dice que su primera salida fue el año 1749 por la costa del oeste del archipiélago entrando por todas sus canales, en el cual viaje levantó el fuerte de Aychilu desde el cual tomaba sus derrotas, y en este viaje corrió hasta la punta de los Tres Montes lo cual no montó por ser muy brava y que opinión de algunos excedía el cabo de Hornos ${ }^{141}$.

Junto con comprobar Brizuela y Evrard en 1750 la no existencia de un enclave inglés en el Pacífico y la inutilidad - por la lejanía y la hostilidad de la geografía y el clima - que tendría en caso de haberlo, se comprobó que las sospechas eran, por el momento, infundadas. Doce años después, en 1762, hay noticia que desde Chiloé su gobernador, Juan Antonio Garretón, cree en la posibilidad de haber población de extranjeros en la costa patagónica, a quienes llama Césares ${ }^{142}$. No sabemos si se ejecutó la expedición que organizaba, pero sí sabemos que el mismo Garretón, al año siguiente, dispuso un nuevo reconocimiento al archipiélago de los Chonos, específicamente a la isla Tenquehuén y a la de Caychilú, Aychilú o San Fernando (donde se

140 Medina, J. (1916), p. 16.

141 Amat y Junient, M. [1760] (1924-1928), 60, p. 417.

142 Garretón informaba al presidente de Chile, Félix de Berroeta, estar preparando una galeota de 17 varas de quilla para una expedición, a ejecutarse en enero siguiente, para hacer personalmente viaje al río de Palena a la parte del sur 10 leguas del Corcovado, porque quiero desengañarme de este formidable río, que por noticias que me han dado los indios guaiguenes interna mucho a la parte del este dejando las cordilleras atrás y me aseguran haber población sin saber qué nación sea y de lo que resultare avisaré a Vuestra Señoría. Garretón alaba la galeota como embarcación más a propósito para internarse en estas canales. Juan Antonio Garretón al presidente Berroeta, Chacao, 8 de enero de 1763. ANH, CG, Vol. 710, fjs. 126 y 126v. 
había construido el fuerte), al mando del ayudante de milicias, José Domínguez. Le dio instrucciones para ir al reconocimiento de la isla de Inche y demás puertos de las Guaitecas [que en realidad es el archipiélago de los Chonos] en Chacao, a 18 de febrero de 1763, señalándole la derrota por la isla Guafo, luego el puerto de San Pablo de Puquitin, y el de la Ascención. Y sigue: bahía de Maurey, puerto de San Diego, bahía de Palgualaguen, puerto de San Martín de Mañez, islas de San Trifón, y finalmente bahía de Tenqueguen, puerto de Apiley [Caychilú o Aychilú], isla de San Fernando ${ }^{143}$. La ruta señalada y los topónimos dan cuenta de lo recorrido y cartografiado por Mateo Abraham en 1750, diario y mapa hasta ahora perdido. El 23 de febrero Domínguez salió desde Castro en una embarcación, al mando de 18 personas entre indios y españoles ${ }^{144}$, pero no hay noticias de los resultados de este viaje, $e$ incluso, a dos años de él, se reclama en Santiago que aun no reciben información de lo ejecutado ${ }^{145}$.

Entre esta expedición y la que sigue, median las misionales al sur del golfo de Penas, de García (1766-1767) y de Vicuña (1767-1768). Para entonces, nuevamente había alarma de la presencia de ingleses en la Patagonia, tanto atlántica como pacífica, con la ocupación inglesa de las islas Malvinas en 1765 y la declaración de guerra, porque por carta fechada en Madrid el 29 de diciembre de 1766, se advierte del intento de establecimiento por los ingleses en alguna isla de esos mares, o los del sur, y acaso en sus $\operatorname{costas}^{146}$, y por la de 4 de enero de 1767, el rey manda al virrey del Perú, Manuel de Amat, que encargue muy particularmente a los gobernadores de todos los puertos de esa jurisdicción que envien embarcaciones menores por las costas de su distrito e islas inmediatas y con especialidad en las de Chiloé al reconocimiento

143 ANH, CG, Vol. 710, fjs. 129-130. Este viaje lo conocí gracias a la referencia que da Hanisch, W. (1982), p. 66.

144 ANH, CG, Vol. 710, f. 128. Le siguen, en fjs.131 a 133, los pertrechos y bastimentos dados a la expedición por los tenientes de oficiales reales, en Chacao.

145 ANH, CG, Vol. 710, f. 133v. Aunque carecemos de más documentación que la citada, es posible que este reconocimiento y búsqueda de los Césares de enero de 1763 sea consecuencia de la declaración de la guerra de España a Inglaterra como consecuencia del Tercer Pacto de Familia. La guerra se mantuvo desde comienzos de 1762 al 10 de febrero de 1763, en que se firmó la Paz de París.

146 A Felipe Ruiz Puente, gobernador de las Malvinas, Madrid, 29 de diciembre de 1766. AGI, Lima, 1118. de si hay establecimientos extranjeros ${ }^{147}$, porque el rey lo tiene por muy cierto. Las costas occidentales serían más vulnerables que las orientales, por los millares de islas que se hayan desde el estrecho de Magallanes hasta Chiloé manifestando que puede verificarse éste en alguno de los territorios de esos dominios sin que en muchos años se sepa ahi porque los hay, que nadie de los nuestros los ha visto ${ }^{148}$. Amat ordenó con precisión al gobernador de Chiloé el inmediato reconocimiento, y que aprestase dos galeotas o pequeños bergantines... [y que] embarcando la gente más escogida registrase isla por isla y visitando cada una de las muchas caletas que forman los caudalosos ríos que descienden de la cordillera, internasen por el estrecho de Magallanes practicando, en el caso de encontrar algún establecimiento, las protestas y requerimientos que se me advierten ${ }^{149}$. Esta fue la expedición dirigida por el piloto Cosme Ugarte y el teniente de infantería Pedro Mansilla, quien iba como comandante y práctico, ejecutada entre diciembre de 1767 y el 1 de mayo de 1768 , conformada por 14 marineros, 16 soldados y 13 indígenas gente del sur, en un barcolongo y dos piraguas. Se sospechaba de establecimientos, específicamente, en la isla Madre de Dios, pero nada encontraron. El recorrido fue por la costa occidental del archipiélago de los Chonos, hasta la isla de San Fernando de Tenquehuén, donde llegaron el 15 de enero. Al avanzar hacia el sur, los pilotos se opusieron a doblar el peligroso cabo de Tres Montes, y el grupo tuvo regresar tomando los canales hacia el este, hasta el inicio de la ruta del istmo de Ofqui, que cruzaron en 9 días, saliendo al golfo de San Javier, para continuar al sur reconociendo hasta los 53 grados, tal como lo ordenaban las Instrucciones, desde donde se devolvieron ${ }^{150}$. En forma paralela, y por iniciativa de

147 El rey al virrey del Perú sobre posible presencia inglesa, Madrid, 4 de enero de 1767. AGI, Lima, 1118.

148 De Julián de Arriaga al virrey Manuel de Amat, San Ildefonso, 20 de agosto de 1767. AGI, Lima, 1498.

149 Del virrey de Lima, Manuel de Amat, a Julián de Arriaga. Lima, 17 de septiembre de 1767. AGI, IG, 412. También en AGI, Lima, 1118

150 "Testimonio de los autos originados en el reconocimiento de la isla de la Madre de Dios y demás adyacentes que de orden de S. Majestad se mandó hacer para ver si había en ellas establecimiento de ingleses", 111 fjs. AGI, IG, 412. En esos Testimonios se halla el "Reconocimiento de costas e islas Guaitecas y Guayaneco por don Pedro Mansilla”, 6 fjs. Se ha encontrado sólo una parte del diario de Cosme Ugarte, en MN, 0135, Ms. 0165/000, fjs. 2-2v. 
Amat, por real cédula de octubre de 1768 Chiloé pasó a depender, en lo temporal directamente del Perú y se comenzó la fundación del fuerte y villa de San Carlos de Chiloé, Ancud. Ambas medidas evidenciaban la mayor importancia estratégica que el virreinato y la Corona dieron a esta provincia, como lo prueba también la Relación de Lázaro de Rivera, quien propone un plan de defensa de Chiloé ${ }^{151}$.

Al regreso a Chiloé de Mansilla y Ugarte se difundió el rumor que, un poco mas delante de donde habían llegado, había una población de europeos ${ }^{152}$. Esta información fue el origen de la expedición siguiente, del piloto Francisco Machado y el teniente José de Sotomayor, quien iba como comandante. Zarparon de Chiloé, con orden de explorar hasta el cabo de Hornos, con una goleta y dos piraguas en conserva, el 17 de diciembre de 1768 y regresaron a Quicaví el 8 de mayo del año siguiente, pero no encontraron lo que buscaban. Contamos con las instrucciones generales y las reservadas dadas por el gobernador de Chiloé, Carlos de Beranger, la bitácora de Machado ${ }^{153}$, y una descripción abreviada del viaje hecha por el propio Machado ${ }^{154}$. Reconoció la isla de Tenquehuén (Aychilú o Caychilú) que sitúa en 45 grados y 47 minutos, la de Inche, el estero de Diego Gallegos, en el puerto donde ancló el Anna, describió la tierra firme que avistó, el golfo de San Esteban, isla de San Javier y las islas de Ayantao, en 47 grados y 32 minutos. Luego la isla de Guayaneco, canal de Fallos, puerto de la Campana y canal Messier, hasta los 49 grados y medio, de todo lo cual va dando información de puertos seguros, bajíos, canales, rocas y distancias.

Al verano siguiente, 1770-1771, tuvo lugar otra expedición, ordenada por real orden de 6 de junio de 1770, para buscar, una vez mas, un establecimiento de extranjeros en el puerto donde había estado el Anna, porque el gobernador de Buenos Aires había

151 Discurso que hace don Lázaro de la Ribera, ingeniero voluntario, sobre la provincia de Chiloé. Lima, 27 de agosto de 1782. En Anrique, N. (1897). Cinco relaciones geográficas e hidrográficas que interesan a Chile. Santiago: Imprenta Elzeviriana.

152 El ex gobernador de Chiloé Manuel de Castelblanco al presidente Guill y Gonzaga, Chacao, 10 de octubre de 1768. AGI, IG, 412.

153 Diario de navegación de don Francisco Machado. MN, 0135, Ms. 0165/000, fjs. 3-14. Instrucción dadas al piloto Francisco Machado para su expedición, mas otra documentación relativa y mapas, fjs. $14 \mathrm{v}-27 \mathrm{v}$.

154 BL, Manuscritos, Mss. Add. 17.593, fjs. 49v-57v. escrito a Madrid que sospechaba fuera ese - y no en el Atlántico - el lugar donde estaban ${ }^{155}$. Aunque el gobernador de Chiloé, Carlos de Beranger, tenía certeza de no haberlos, por la prolijidad de la expedición inmediatamente anterior, y las antecedentes, tuvo que ejecutarlo. Envió al teniente de artillería José Rius, quien salió en dos piraguas, junto al alférez de dragones Pedro Mansilla, veterano ya del viaje, del puerto de Queil, isla de Quinchao, el 2 de noviembre de ese año para el reconocimiento del puerto del pingüe Ana y demás parajes que consideré precisos ${ }^{156}$. Rius reconoció los puertos del Anna, Diego Gallego, islas de Inchin (Inche) y San Fernando, constató lo hostil del territorio como para asentarse en él, y regresó llegando a San Carlos sin haber encontrado rastro ni noticias de extranjeros, el 28 de diciembre del mismo año ${ }^{157}$.

Desde el regreso de Rius, en diciembre de 1771, no hubo mas expediciones en busca de establecimientos de ingleses, o no ha llegado información a nosotros de haberse ejecutado. $\mathrm{O}$ el resultado de las expediciones informadas por Beranger había sido suficiente, o se hizo sentir lo firmado en enero de 1771, sobre el no rompimiento entre España e Inglaterra ${ }^{158}$. Mediaron entre ambas, eso si, las expediciones misionales de

155 Véase Navarro, M. C. (1999). Las expediciones marítimas de Francisco Machado y José Rius (Chiloé, 1768-1770). En C. Martínez (coord.). Historia moderna, historia en construcción (Vol. 1, pp. 175-190). Lleida: Milenio,

156 Carlos de Beranger, gobernador de Chiloé, al virrey del Perú, Manuel de Amat, San Carlos de Chiloé, 4 de enero de 1771. AGI, Lima, 1035.

157 El Diario está en AGI, Lima, 1035. También en AGI, Chile, 219. Correspondencia e instrucciones en AGI, Chile, 435. Casi no se veían indígenas en estos últimos viajes, por lo que Beranger escribe que el archipiélago de las Guaitecas, o de los Guafos y Chonos, todas sus islas son deshabitadas, como la costa de tierra firme que corre hasta la punta de Taytauhunhuon con el puerto del Pingüe Ana, y estero de Diego Gallego, que comprende, bien que los indios guayguenes y chonos tramitan continuamente este archipiélago como ambulantes y dispersos a la pesca de lobos y mariscos sin tener estabilidad y reducidos a chozas portátiles de ramas y cueros. Beranger, Carlos de, Relación Geográfica de la isla de Chiloé y su archipiélago, provincia del reino de Chile y la más austral de América Meridional en la cual se expresa su posición, figura, confines, tierras adyacentes, sus puertos, comercio y temperamento. Asimismo todo lo demás que conduce a la mayor inteligencia de su extensión e importancia, como las cosas notables y particulares que pueden dar una perfecta idea política y militar de ella. Firmada en el año de 1773 BL, Manuscritos, Mss. Add. 17.593, fjs. 1-47v, fjs. 6-6v.

158 Guarda, G. (1990), p. 36 
los franciscanos al sur del golfo de Penas, siendo las documentadas las de 1778-1779 y 1779-1780. En el contexto de la habilitación de la ruta del cabo de Hornos, y la sospecha de una ocupación inglesa como refugio o como colonia comercial, luego de la convención de España e Inglaterra, que se firmó en octubre de 1790, para regular el derecho de Inglaterra a la navegación y pesca en el Pacífico, y asociado a ello a desembarcar en costas no ocupadas por los españoles, por real orden de 25 de diciembre de ese año se dispuso que se adelantaran los reconocimientos al sur de Chiloé, por cuanto se temía que los ingleses quisieran tomarse algunas de las muchas islas desiertas inmediatas a Chiloé y dentro de su archipiélago e introducir su comercio $^{159}$. Por lo cual, por disposición del virrey del Perú en 1792 se dispuso una nueva expedición de reconocimiento, la que tenía nuevamente como objetivo de hacer un examen de las costas, islas y archipiélagos que comienzan desde Chiloé, denominados de los Chonos, Guaitecas y siguientes hasta cabo Victoria, demarcando puertos, bahías, ensenadas, abras, canales y demás puntos de atención, con la exactitud en las observaciones, planos y derroteros... Señala en forma específica el reconocimiento de Inchin, donde estuvo el Anna, y un canal existente entre el cabo Corso y la isla Madre de Dios, a los 50 grados $^{160}$. Para eso puso a disposición del presidente de Chile la fragata Santa Bárbara, comandada por Nicolás Lobato y Cuenca. En Chiloé, la expedición se organizó en las dos piraguas del rey, y no en la Santa Bárbara, una de ellas al mando del alférez de navío Francisco Clemente y Miró, y la

159 Resumen del Ministerio sobre una representación de González de Agüeros, Madrid, 15 de marzo de 1793. AGI, Lima, 1607.

160 "Instrucciones del virrey O"Higgins al comandante de la fragata Santa Bárbara, 7 de noviembre de 1791", en Medina, J. (1889). Ensayo acerca de una Mapoteca Chilena, o sea, de una colección de los títulos de los mapas, planos y vistas relativos a Chile arreglados cronológicamente. Santiago: Imprenta Ercilla, pp. 244-248. También hay cartas del virrey O"Higgins al conde de Floridablanca, dando cuenta de las resultas del viaje, pp. 249-254. En la segunda carta, de 20 de mayo de 1792, el virrey dice que recibió del gobernador de Chiloé el diario del viaje hecho por un sargento, "reducido a los sucesos del viaje". Tanto este dato, como el de la cita siguiente, los conocí por Hanisch, W. (1982), pp. 84 y 86. Sagredo y González refieren ambas cartas de BN, MM, doc. 4.554, T. 201, fjs. 106-108, y doc. 4.956, T. 201, fjs. 111-115, en Sagredo, R., González, J. (2004). La expedición Malaspina en la frontera austral del Imperio Español. Santiago: Centro de Investigaciones Diego Barros Arana y Editorial Universitaria, pp. 765-769. otra al también alférez de navío Luis Lasqueti. El viaje se realizó desde el 7 de enero al 3 de marzo de 1792, y no pasaron mas al sur de la latitud del puerto de Inche ${ }^{161}$

En las expediciones de búsqueda de establecimientos de ingleses de la segunda mitad del siglo XVIII no hubo intención de fundar una colonia o un fuerte. Sus orígenes estuvieron en las órdenes dadas en Madrid, donde se tenía una imagen y concepto distinto de las circunstancias geográficas, humanas e históricas de las costas patagónicas occidentales, del que se tenía en Chile y particularmente en Chiloé, provincia de antigua y permanente relación con aquellas costas y sus habitantes. Los patrullajes deben haber sido periódicos, y en manos de indígenas solos o al mando de algún militar -cabo-, salidos de Chiloé en dalcas o piraguas cada verano, sin mediar orden ni comunicación con la autoridad de Santiago o de Lima. De ellos nada de sabe, por ser salidas menores, pero algunas referencias tenemos, como el patrullaje del chono Martín Olleta, en 1742, que halló a los náufragos ingleses, o que se afirma que hay salidas en los tiempos oportunos de noviembre hasta abril, que se hacen en canoas desde el puerto de Chacao a las islas del archipiélago de los chonos y Guaitecas ${ }^{162}$.

8. Expediciones de interés científico: Moraleda, 1793 y 1794.

En 1786 llegó a Chiloé a asumir el mando de la provincia, como primer gobernador-intendente, Francisco Hurtado del Pino, con el encargo de hacer un completo reconocimiento de los archipiélagos, bahías y puertos, levantar mapas y hacer descripciones, tarea que se encomendó al piloto José de Moraleda y Montero, que se hallaba momentáneamente en Perú a bordo de un navío de guerra. El objetivo no era expresamente buscar establecimientos de extranjeros, sino tener un mejor conocimiento geográfico de Chiloé, posesión que la Corona valoraba como la llave del Mar del Sur desde la gestión del presidente Manuel de Amat (1755-1761), y más aún desde su actuar como virrey (1761-1776). Pero además, habría que sumar a esta preocupación estratégica, la geográfica e hidrográfica propia de las últimas décadas del siglo XVIII, en que

161 El Diario de Clemente y Miró está en BN, MM, Vol. 209, fjs. 10-107.

162 El presidente Guill y Gonzaga a Julián de Arriaga. AGI, IG, 412. 
la Corona buscó actualizar la información sobre sus colonias con el fin de activarlas económicamente $e^{163}$, y la motivación científica ${ }^{164}$. Entre estos tres objetivos habría que ubicar al piloto Moraleda quien, como dice Hanisch, con su trabajo, estudió en Chiloé la frontera que divide las tierras de las aguas y sus mutuas relaciones ${ }^{165}$. Entre 1787 y 1788 hizo dos viajes para dar la vuelta completa en torno a la isla grande de Chiloé, describiéndola desde el mar y desde todos sus flancos, tarea no realizada hasta entonces, así como las costas de la tierra firme chilota del norte: Carelmapu y Calbuco ${ }^{166}$. Habiendo finalizado su encargo, y además, informando y colaborando a la expedición de Malaspina y Bustamante en su paso por Chiloé en 1792, regresó en ese mismo año al Perú, y otra vez, antes de finalizarse ese año, envió el virrey a Moraleda a hacer un nuevo reconocimiento, esta vez a los canales y archipiélagos al sur de Chiloé. Con dos piraguas grandes, una piloteada por él y otra por José de Torres, zarpó rumbo al sur, el 21 de enero de 1793, y regresó a San Carlos el 2 de mayo de ese año, habiendo recorrido y descrito gran parte del enorme archipiélago de los Chonos, hasta la altura del río Aysén, el que exploraron con prolijidad. Continuó la comisión al año siguiente, desde el 11 de febrero al 18 de mayo de 1794.

En su cuidadoso reconocimiento alcanzó hasta la latitud de 44 grados, enfocándose principalmente al estudio del río Palena ${ }^{167}$. Sus escritos y mapas son tan completos que en 1888 se les ponderaba como superiores a los realizados hasta entonces, a pesar de lo ejecutado por la Armada de Chile. Describe mareas, distancias en leguas, profundidad del mar, vientos, puertos naturales, vegetación, y además realiza anotaciones de interés etnográfico sobre indígenas y marineros chilotes,

163 Weber, D. (2007). Bárbaros. Los españoles y sus salvajes en la era de la Ilustración. Madrid: Editorial Crítica.

164 Sagredo, R. (2009). Navegación científica en el Mar del Sur. El piloto Moraleda (1772-1810). Revista de Historia Iberoamericana, 2(1), 46-79. Sagredo, R. (2010). Navegando entre ríos de nieve. El piloto Moraleda en la costa Patagónica. Revista eletrônica Documento/Monumento [recurso eletrônico), 3(1). Cuiabá: Universidade Federal de Mato Grosso, Núcleo de Documentação e Informação Histórica Regional.

165 Hanisch, W. (1982), p. 87.

166 O'Donnell y Duque de Estrada, H. (1990). El viaje a Chiloé de José de Moraleda (1787-1790). Madrid: Editorial Naval.

167 Moraleda, J. (1888). Exploraciones jeográficas e hidrográficas de José de Moraleda y Montero. Introducción de Diego Barros Arana, Documentos para la Historia Náutica de Chile. Santiago: Imprenta Nacional. amén de objetos asociados a la navegación patagónica, como el cochai. Por último, entre febrero y abril de 1795, estudió el seno del Reloncaví, y en abril del año siguiente regresó al Perú, donde siguió prestando servicios. Entrelazada con la expedición de Moraleda a las costas patagónicas al sur de Chiloé se encuentra la de Alejandro Malaspina y José de Bustamante, de 1789 a 1794, con el objetivo de hacer un viaje político y científico hacia todas las posesiones ultramarinas españolas, en las fragatas Descubierta y Atrevida y que pasó por Chile y Chiloé en $1790^{168}$. El viaje fue, esta vez, de sur a norte, y debido a la envergadura de las dos corbetas, no hubo cercanía ni descripción de la costa patagónica occidental ${ }^{169}$.

\section{CONCLUSIONES}

Desde la llegada de los españoles a las tierras de Chile (1541) y sobre todo a las de Chiloé (1567), y hasta fines del período de dominación española, es posible distinguir etapas, con sus respectivas pulsaciones, en la proyección de Chiloé a la Patagonia Occidental Insular, como una frontera móvil.

Hemos distinguido ocho etapas, y ellas tienen distintas motivaciones. Una primera la constituyen dos expediciones salidas desde las recién fundadas Valdivia o Concepción con el objetivo de navegar rumbo al sur y detectar la boca occidental para entrar al estrecho de Magallanes. Fueron navegaciones cercanas a la costa, por lo que se hicieron las primeras descripciones de tierras y de gentes y se reveló una geografía tan disímil a la del Chile Central que tanto ponderaba Pedro de Valdivia. Con la frustración de las colonias del estrecho de Magallanes, de 1584, perdió fuerza el interés por financiar estas expediciones

168 Sagredo, R., González, J. (2004).

169 La navegación entre las islas Malvinas y Ancud se hizo entre enero y febrero de ese año, y aunque las instrucciones determinaban fijar los limites en longitud de la costa occidental patagónica desde el cabo Victoria hasta Chiloé, para la mayor seguridad de la navegación nacional en estos mares, Malaspina, ya en terreno, consideró que los puntos podían ya considerarse como situados con la mayor exactitud hidrográfica por viajes ingleses, Francisco Machado y José de Moraleda, restando como único trozo no bien conocido el comprendido entre los 52 y 49 grados de latitud sur. Sólo avistaron la tierra desde los barcos, y a la latitud prevista se retiraron mar afuera para tomar derrota a Chiloé. Alejandro Malaspina. Navegación desde el Puerto Egmont al de San Carlos de Chiloé, en Sagredo, R., González, J. (2004), pp.183-214. 
costeras. Una segunda etapa es la propia de los recién creados centros españoles hacia sus fronteras, con tanteos para enterarse del territorio al sur de la isla grande de Chiloé y de sus posibilidades económicas (captura de indígenas), que decreció en la medida que la población originaria, producto de su captura, traslado y venta, disminuyó numéricamente. Pero en su período final (1610-20) coincide con la tercera etapa, la de los viajes de los misioneros jesuitas del colegio de Castro hacia el archipiélago de las Guaitecas, para intentar establecer una misión y atender espiritualmente a los indígenas, no sujetos a encomienda por lejanos y bárbaros, y ocupados sólo como mercancías. El intento no dio resultado, pero la interacción con los chonos, a través de los jesuitas, hizo crecer el rumor de la existencia de una o más poblaciones de extranjeros o de españoles asentadas en algún punto de la inmensidad de la Patagonia, lo que motivó una cuarta etapa, de búsqueda de los llamados Césares en expediciones ordenadas desde el virreinato, y que tuvo su punto álgido con Vea y Gallardo, entre 1674 y 1676 , pero que al no hallar nada se produjo una perdida del interés oficial por este asunto. La quinta etapa comprende nuevamente la atención económica al archipiélago de los Chonos, con nuevas entradas para capturar indígenas, documentadas a fines del siglo XVII y comienzos del XVIII, consecuencia de las llegadas cada vez más al sur de la etapa anterior. En una sexta etapa, el naufragio de la Wager en el archipiélago de Guayaneco reabrió una geografía olvidada al sur del golfo de Penas y unos indígenas nuevos a quienes atender, esta vez, sólo espiritualmente, todo lo cual se desarrolló entre 1742 y 1780 . La séptima etapa es la de las expediciones para patrullar la Patagonia insular ante la sospecha de la instalación de una colonia o la habilitación de un puerto inglés en el área de la península de Taitao, no explorado hasta entonces, porque los recorridos hacia el sur se hacían por el mar interior, a través de los canales Moraleda y Messier, lo que se extendió desde 1750 a 1792. Por último, la octava etapa, a fines del siglo XVIII, con los reconocimientos de Moraleda, y en parte, los de Malaspina y Bustamante, se explica por el interés científico de conocer, medir y registrar.

Todas estas expediciones referidas son de las que existe documentación o alguna información. Sin embargo, no podemos suponer que no haya habido viajes de particulares de hispano-criollos, de indígenas o encomendados por el gobernador de Chiloé, con distintos fines. El papel era muy escaso en Chiloé, la comunicación muy a lo lejos (una vez al año, normalmente) y los naufragios, frecuentes. Además, como ya hemos dicho, las salidas de indígenas hacia el sur eran parte de su manera de vivir, y a ellos se les encargaba dar cuenta de las novedades.

En todos los casos, se va con prácticos indios, tanto los que se van encontrando en el camino, como otros que son veteranos de viajes anteriores, además de milicianos chilotes, con bastimentos para todo el viaje -por la dificultad de abastecerse de algo en el camino-, planos y cartas de viajes existentes en el archivo del palacio del gobernador de Chiloé. Los indígenas tanto chilotes o veliches, como chonos, guaiguenes y caucahués era los guías naturales, pero también eran vitales remeros, mariscadores, y las indias, buzas.

Es de suponer, también, viajes particulares de chilotes a fines del siglo XVIII (como los famosos Barrientos, de Quiquel) a las islas del sur, y a las costas de la actual provincia de Palena y región de Aysén, cuya consecuencia fue la explotación del ciprés y de los alerzales de las Guaitecas y la cordillera, asî como la caza del lobo, y quizá, las balleneras. La gran movilidad de los indígenas llamados canoeros por la larga costa patagónica es quizá difundida a los hispano-criollos y mestizos hijos de esa geografía.

Por último, la interacción con esos indios es distinta en el XVI, que es de indiferencia; en el XVII, de interés por su traslado y esclavitud, de misionarlos en sus propias islas y ocuparlos de guías hacia los Césares; y en el XVIII para trasladarlos a Cailín para su conversión, y para valorarlos como aliados, atrayéndolos antes que los ingleses. La actitud sobre las tierras también es distinta, porque transita desde un espacio intermedio entre Chiloé y el estrecho de Magallanes, carente de interés; a uno que proveía de riquezas materiales (piezas, Césares) u objetos de conversión; y a otro de costas que habría que recorrer y patrullar por su valor geopolítico.

\section{FUENTES DE CONSULTA}

\section{a) Manuscritos}

\section{AAS, Archivo Arzobispal de Santiago, Chile.}

ANH, CG Archivo Nacional Histórico (Santiago de Chile), Capitanía General, Vol. 379, 385, 487, 527, 710. 
ANH, FV Archivo Nacional Histórico (Santiago de Chile), Varios, Vol. 139, 141.

ANH, MV Archivo Nacional Histórico (Santiago de Chile), Morla Vicuña, Vol. 4, pzas 187 a 191, 192 y 194-195.

ANH, VG Archivo Nacional Histórico (Santiago de Chile), Vidal Gormaz, Vol. 7, pza. 4 y 8; Vol. 9, pza. 16.

ANH, RA Archivo Nacional Histórico (Santiago de Chile), Real Audiencia, Vol. 1691, pza. 15.

AGI, Chile Archivo General de Indias (Sevilla), Audiencia de Chile, legajos 98, 188, 219, 240, 433, 435.

AGI, IG Archivo General de Indias (Sevilla), Indiferente General, legajo 412.

AGI, Lima Archivo General de Indias (Sevilla), Audiencia de Lima, legajos 643, 1118, 1035, 1498, 1607.

AGI, MP, Perú-Chile Archivo General de Indias (Sevilla), Mapas y Planos, Perú y Chile, mapas 34, 34BIS y 34 TER.

AGI, Patronato Archivo General de Indias (Sevilla), Patronato, 32, R. 5; 33, N.1, R.1.

ARSI, Chile Archivum Romanun Societas Iesu (Roma) Provincia de Chile, Vols. 4, 5, 6, 8.

MNM Museo Naval de Madrid, manuscritos 0145, Ms. 0191/005, 0135, Ms. 0165/000.

BL, The British Library (Londres) Manuscritos, Mss. Add. 17.593.

BN, MM Biblioteca Nacional (Santiago de Chile), Manuscritos Medina, Vol. 270, 209.

\section{b) Impresos}

AA.VV. (2012) Cuatro relatos para un naufragio. La fragata Wager en el golfo de Penas. Santiago: Ediciones Septiembre.

AA.VV. [1609-1614] (1927). Cartas Anuas de la Provincia del Paraguay, Chile y Tucumán, de la Compañía de Jesús (1609-1614). Documentos para la historia argentina, T. XIX, Iglesia. Buenos Aires: Talleres S.A. Casa Jacobo Peuser, Ltda.

Alfonso, J. [1931] (1966). ¿Todavía la Patagonia? Revista Chilena de Historia y Geografía, 134, 82-85

Álvarez, R. (2002). Reflexiones en torno a las identidades de las poblaciones canoeras situadas entre los $44^{\circ}$ y $48^{\circ}$ de latitud sur, denominadas 'chonos'. Anales del Instituto de la Patagonia, 30, 79-86.

Amat y Junient, M. [1760] (1924-1928). Historia geographica e hidrográfica con el derrotero general correlativo al plan del reino de Chile que remite a Nuestro Monarca el Señor Don Carlos III. Revista Chilena de Historia y Geografía, 53, 297-344; 54, 337- 392; 55, 425-458; 56, 360-401; 57, 393-492; 58, 407-422; 59, 353-379; 60, 394-426; 61, 318-333; 62, 305-337.
Amunátegui, M. (1879-1880). La cuestión de límites entre Chile y la República Argentina. Santiago: Imprenta Nacional.

Anrique, N. (1984). Bibliografía Marítima Chilena. Santiago: Imprenta Cervantes.

Barros, J. (1981). Expedición al estrecho de Magallanes en 1553: Gerónimo de Vivar y Hernando Gallegos. Anales del Instituto de la Patagonia, 12, 31-40.

Bazán, R. (1986). El patrimonio que recibimos del Reino de Chile. Santiago: Universidad de Santiago.

Benavente, M. (1983). Más sobre la expedición marítima del comodoro inglés Anson a las costas sudamericanas y la flota española del almirante Pizarro. Boletín de la Academia Chilena de la Historia, 94, 285-289.

Campbell, A. (1747). The sequel to Bulkeley and Cummins's voyage to the South-Seas: or the adventures of capt. Cheap, the Hon. Mr. Byron, Lieut, Hamilton, Alexander Campbell and others, late of his majesty's ship The Wage, wich was wreck'd on a desolate island. Londres: W. Owen.

Campos, F. (1969). Don García Hurtado de Mendoza en la Historia Americana. Santiago: Editorial Andrés Bello.

Canseco, A. (1982). La escuadra de Jorge Anson y José Pizarro en el Atlántico austral. En Argentina. Departamento de Estudios Histórico Navales. Historia marítima argentina (pp. 349-375). Buenos Aires: Editorial Cuántica, T. III, cap. XIV.

Carabias, D. (2009). Encuentro de dos mundos. Naufragio del H.M.S. Wager en la Patagonia. Arqueología histórica en el golfo de Penas: investigación de los restos de la fragata Wager (1741), archipiélago de Guayaneco, XI región de Aysén. Santiago: Productora Gráfica MC4, Consejo Nacional de la Cultura y las Artes.

Carvallo Goyeneche, V. [1796]. Descripción histórico-geográfica del reino de Chile por don Vicente Carvallo i Goyeneche, precedida de una biografía del autor por don Miguel L. Amunátegui. En Medina, J. (1865). Colección de historiadores de Chile y de documentos relativos a la Historia Nacional, T. IX. Santiago: Imprenta de la Estrella.

Casanueva, F. (1982). La evangelización periférica en el Reino de Chile. Nueva Historia, 5, 5-30.

Contreras, J., Flores, E., Herrera, I., Mazzei, L., Rivera, A. \& Romero, R. (1971). La población y la economía de Chiloé durante la Colonia, 1567-1826: un ensayo de interpretación. Concepción: Universidad de Concepción.

Donoso, R., Irarrázaval, J. (1966). Barros Arana y la pérdida de la Patagonia. Revista Chilena de Historia y Geografía, 134, 67-81.

Finsterbusch, C. (1934). Las dalcas de Chiloé y los chilotes. Santiago: Imprenta Universitaria. También en (1934). 
Revista Chilena de Historia y Geografía, 82, 412-433.

Fitz-Roy, R. (1839). Narratives of the surveying voyages of H.M.S. Adventure and Beagle between the years 1826 and1836 Describing their examination of the southern shores of South Americ and the Beagle's circunnavigation of the globe. Londres: Henry Colbun.

Fonck, F. (1900). Viajes de fray Francisco Menéndez a NahueIhuapi. Valparaíso: Imprenta Guillet.

Gallardo, B. [1675] (1886). Relación del sargento mayor don Bartolomé Gallardo hecha en Lima de orden de V. E. sobre el viaje que hizo en reconocimiento a las poblaciones de los ingleses con todo lo sucedido en él y paraje donde llegó (1674-1675). Anuario Hidrográfico de la Marina de Chile, 9, 525-537.

García, Pedro [1766-1767]. Diario del viaje y navegación hecho por el padre Joseph García de la Compañía de Jesús desde su misión de Kailín, en Chiloé, hacia el sur. Año 1766. En Von Murr, Gottlieb (1811). Nachrichten von verschiedenen Landern des spanischen Amerika (pp. 506-598). Halle: Verlegt bev Joh. Christian Hendel.

González de Agüeros, P. (1791), Descripción historial de la provincia y archipiélago de Chiloé en el reino de Chile, y obispado de la Concepción. Madrid: Imprenta de Don Benito Cano.

González-Barrera, J. (2010). La derrota a través del Estrecho de Magallanes: El viaje olvidado de Juan Ladrillero (1557-1559). Atenea, 501, 11-33.

Guarda, G. (1990). Flandes Indiano. Las fortificaciones del reino de Chile. Santiago: Universidad Católica de Chile.

Guarda, G. (2002). Los encomenderos de Chiloé. Santiago: Ediciones de la Universidad Católica de Chile.

Hanisch, W. (1982). La isla de Chiloé, capitana de rutas australes. Santiago: Academia Superior de Ciencias Pedagógicas de Santiago.

Hermosilla, N. \& Ramírez J. (1982). Reconstrucción autorizada de la expedición de Juan de Ladrillero a la Patagonia Occidental: 1557-1599. Anales del Instituto de la Patagonia, 13, 59-71.

Irarrázaval, J. [1930] (1966). La Patagonia. Errores geográficos y diplomáticos. Santiago: Editorial Andrés Bello.

Jara, A. (1971). Guerra y sociedad en Chile: la transformación de la Guerra de Arauco y la esclavitud de los indios. Santiago: Editorial Universitaria.

Latcham, R. (1930). La dalca de Chiloé y los canales patagónicos. Boletín del Museo Nacional de Historia Natural, 13, 63-72.

Lozano, P. (1755). Historia de la Compañía de Jesús en la Provincia de Paraguay. Madrid: Imprenta de la viuda de Manuel Fernández y del Supremo Consejo de la
Inquisición.

Malaspina, A. [1789-1790]. Navegación desde puerto Egmont al de San Carlos de Chiloé. En Sagredo, R.; González, J. (2004). La expedición Malaspina en la frontera austral del Imperio Español. Santiago: Centro de Investigaciones Diego Barros Arana y Editorial Universitaria.

Mariño de Lobera, P. Crónica del reino de Chile. En Medina, J. (1865). Colección de historiadores de Chile y documentos relativos a la historia nacional, T. VI. Santiago: Imprenta el Ferrocarril

Martín, M. (1986). Derrotero de la costa pacífica americana. JANO, 709 (2).

Martinic, M. (1977). Historia del Estrecho de Magallanes. Santiago: Editorial Andrés Bello.

Martinic, M. (1992). Historia de la Región Magallánica. Punta Arenas: Universidad de Magallanes.

Martinic, M. (2004). Archipiélago Patagónico. La última frontera. Punta Arenas: Ediciones de la Universidad de Magallanes.

Martinic, M. (2005). De la Trapananda al Aysén. Santiago: Pehuén Editores.

Medina, A. (1984). Embarcaciones chilenas precolombinas. La dalca de Chiloé. Revista Chilena de Antropología, 4, 121-138

Medina, J. (1916). Primer viaje de exploración a la isla de Tenqueguen, Diario y derrotero de don Manuel Brizuela (1750). Revista Chilena de Historia y Geografía, 23, 5-29. También en Medina, J. (1962). Viajes relativos a Chile (Tomo I, pp. 145-165). Santiago: Fondo Histórico y Bibliográfico José Toribio Medina.

Monge, J. (1944, 1945 y 1946). El istmo de Ofqui. Revista Chilena de Historia y Geografía, 105, 5-44; 106, 62 102; 107, 296-338; 108, 117-156.

Moraleda, J. (1888). Exploraciones geográficas e hidrográficas de José de Moraleda y Montero, Introducción de Diego Barros Arana, Documentos para la Historia Náutica de Chile. Santiago: Imprenta Nacional.

Moreno, R. (2007). Misiones en Chile austral: los jesuitas en Chiloé, 1608-1768. Sevilla: Consejo Superior de Investigaciones Científicas: Escuela de Estudios HispanoAmericanos, Universidad de Sevilla y Diputación de Sevilla.

Morla, C. (1903). Estudio histórico sobre el descubrimiento y conquista de la Patagonia y Tierra del Fuego. Leipzig: F.A. Brockhaus.

Navarro, L. (1994). Francisco de Ulloa. Explorador de California y Chile austral. Badajoz: Departamento de Publicaciones, Excma. Diputación Provincial de Badajoz.

Navarro, M. (1999). Las expediciones marítimas de Francisco 
Machado y José Rius (Chiloé, 1768-1770). En Martínez, C. (coord.). Historia moderna, historia en construcción (Vol. 1, pp. 175-190). Lleida: Milenio.

O’Donell \& Duque de Estrada, H. (1990). El viaje a Chiloé de José de Moraleda (1787-1790). Madrid: Editorial Naval.

O'Higgins, A. (1791). Instrucciones del virrey O'Higgins al comandante de la fragata Santa Bárbara, 7 de noviembre de 1791. En Medina, J. (1889). Ensayo acerca de una Mapoteca Chilena, o sea, de una colección de los títulos de los mapas, planos y vistas relativos a Chile arreglados cronológicamente (pp. 244-248). Santiago: Imprenta Ercilla.

Olguín, C. (1971). Instituciones políticas administrativas de Chiloé en el siglo XVIII. Santiago: Editorial Jurídica de Chile.

Olivares, M. [1736]. Historia de la Compañía de Jesús en Chile (1593-1736). En Medina, J. (1874). Colección de historiadores de Chile y de documentos relativos a la Historia nacional, T. VII. Santiago: Imprenta Andrés Bello.

Osorio, M. (2007). Aysén, matices de una identidad que asoma. En Osorio, M., Saavedra, G., H. Velásquez. Otras narrativas en Patagonia. Tres miradas antropológicas a la región de Aysén (pp. 9-33). Coyhaique: Ediciones Nirre Negro.

Ovalle, A. [1646] (2003). Histórica relación del reino de Chile. Santiago: Pehuén Editores.

Oyarzún, J. (1999). Expediciones españolas al estrecho de Magallanes y Tierra del Fuego. Madrid: Ediciones de Cultura Hispánica, Agencia Española de Cooperación Internacional.

Puente, M. (1986). La "dalca" de Chiloé. Su influencia en la exploración austral. Contribución a su estudio. Revista de Historia Naval, 15, 19-44.

Quiroz, D. (1985). La expedición del piloto Juan García Tao a la Patagonia Occidental Insular (1620-1621). Boletín del Museo Mapuche de Cañete, 1, 56-61.

Quiroz, D. \& Olivares, J. (1988). Nómades canoeros de la Patagonia septentrional Insular: el mundo de don Pedro del Agua. En Silva, O., Medina, E., Téllez, E. (edit.). Encuentro de etnohistoriadores (pp. 10-33). Santiago: Departamento de Ciencias Históricas, Universidad de Chile.

Ribera, L. [1782]. Discurso que hace don Lázaro de la Ribera, ingeniero voluntario, sobre la provincia de Chiloé. Lima, 27 de agosto de 1782. En Anrique, N. (1897). Cinco relaciones geográficas e hidrográficas que interesan a Chile. Santiago: Imprenta Elzeviriana.

Rosales, D. [c.1670] (1877). Historia General del Reino de Chile. Flandes Indiano. Valparaíso: Imprenta del Mercurio.

Rosales, D. [c.1670]. Vida del Padre Juan López Ruiz. En Val- dés, G. (1991) (Introducción, Traducción y Notas). Seis misioneros en la frontera mapuche (Del Libro IV de la Conquista Espiritual del Reino de Chile, Volumen I, de Diego de Rosales). Temuco: Centro Ecuménico Diego de Medellín, Ediciones de la Universidad de la Frontera.

Rosso, G. (1950). Nicoló Mascardi missionario gesuita del Cile e della Patagonia (1624-1674). Archivum Historicum Societatis Iesu, 45, 3-74.

Saavedra, G. (2007). Desarrollo endógeno y dinámicas de significación cultural en el borde costero del sur austral chileno. En En Osorio, M., Saavedra, G., H. Velásquez. Otras narrativas en Patagonia. Tres miradas antropológicas a la región de Aysén (pp. 235-265). Coyhaique: Ediciones Nirre Negro.

Sagredo, R. \& González, J. (2004). La expedición Malaspina en la frontera austral del Imperio Español. Santiago: Centro de Investigaciones Diego Barros Arana y Editorial Universitaria.

Sagredo, R. (2009). Navegación científica en el Mar del Sur. El piloto Moraleda (1772-1810). Revista de Historia Iberoamericana, 2 (1), 46-79.

Sagredo, R. (2010). Navegando entre ríos de nieve. El piloto Moraleda en la costa Patagónica. Revista eletrônica Documento/Monumento [recurso eletrônico), 3(1), 51-72. http://200.17.60.4/ndihr/revista-3/artigos/ rafael-sagredo.pdf.

Serrano, R. (1886). Reconocimiento del río Buta-palena y del canal de Fallos por el vapor de la República, "Toro". Anuario Hidrográfico de la Marina de Chile, 9, 72-202.

Simpson, E. (1874). Exploraciones hechas por la corbeta Chacabuco al mando del capitán de fragata don Enrique M. Simpson en los archipiélagos de Guaitecas, Chonos y Taitao. Santiago: Imprenta Nacional.

Steffen, H. (2009). Patagonia Occidental: las cordilleras patagónicas y sus regiones circundantes. Descripción del terreno basada en exploraciones propias con un bosquejo de la historia de las expediciones practicadas en la región. Edición de Eugenio Aspillada y Luis Catalán. Santiago: La Silla.

Steffen, H. (2010). Viajes de exploración y estudio en la Patagonia Occidental: 1892-1902. Santiago: Biblioteca Bicentenario, Dirección de Bibliotecas, Archivos y Museos.

Techo, N. [1673] (2005). Historia de la provincia del Paraguay de la Compañía de Jesús. Asunción: Centro de Estudios Paraguayos Antonio Guash, Fondec.

Thayer, T. (1918). Cuestiones de Geografía austral de Chile. Revista Chilena de Historia y Geografía, 29, 161-217.

Thayer, T. (1918). Estudio históricos sobre las regiones de los coronados y de los rabudos. Revista Chilena de Historia 
y Geografía, 32, 155-200.

Thayer, T. (1919). Importancia que tenían para los españoles las regiones patagónicas. Revista Chilena de Historia y Geografía, 36, 324-342.

Torres, M. (2004). Un best seller del siglo XVIII: el viaje de George Anson alrededor del mundo. Biblio 3W, Revista Bibliográfica de Geografía y Ciencias Sociales (serie documental de Geo Crítica), 531, 1-27.

Urbina, M.X. (2008). La frustrada misión estratégica de Nahuelhuapi, un punto en la inmensidad de la Patagonia. Magallania, 36(1), 5-30.

Urbina, M.X. (2010). La navegación por los canales australes en la Patagonia occidental insular en los siglos coloniales: la ruta del istmo de Ofqui. Magallania, 38(2), 41-67.

Urbina, M.X. (2013a). Traslados de indígenas de la Patagonia occidental insular a Chiloé en los siglos XVI, XVII y XVIII. En Valenzuela, J. (ed.). América en diásporas: esclavitudes y migraciones forzadas (siglos XVI-XIX). Santiago: Instituto de Historia, Pontificia Universidad Católica de Chile/RiL editores (en proceso editorial).

Urbina, M.X. 2013b. Expediciones desde Chiloé para recoger el metal del barco inglés Wager de la flota de George Anson, naufragado en el Pacífico austral en 1741: el conflicto del hierro en Chiloé. Manuscrito inédito.

Urbina, M.X. \& Chapanoff, M. (2010. El protagonismo de la dalca en las navegaciones australes coloniales. Actas de las Jornadas de Historia Naval y Marítima de Chile, 5, 63-72.

Urbina, R. (1986). La dalca chilota de los siglos XVII y XVIII. Chiloé, 6.

Urbina, R. (1991). Las misiones franciscanas de Chiloé a fines del siglo XVIII: 1771-1800. Valparaíso: Ediciones Universitarias de Valparaíso.

Urbina, R. (1998). Gobierno y sociedad en Chiloé colonial. Valparaíso: Editorial Puntángeles.

Urbina, R. (2004). Población indígena, encomienda y tributo en Chiloé: 1567-1813. Politica estatal y criterios locales sobre el servicio personal de veliches y payos. Valparaíso: Ediciones Universitarias de Valparaíso.

Urbina, R. (2007). El pueblo chono: de vagabundo y pagano alzado a cristiano y sedentario amestizado. En Navarro, F. (ed.). Orbis Incongnitus. Avisos y Legajos en el Nuevo Mundo. Homenaje al Profesor Luis Navarro García (Vol. I, pp. 325338). Huelva: Publicaciones de la Universidad de Huelva.

Urbina, R. [1983] 2012. La periferia meridional indiana. Chiloé en el siglo XVIII. Valparaíso: Ediciones de la Pontificia Universidad Católica de Valparaíso.

Vásquez de Espinoza, A. [1619] (1986). Descripción del reino de Chile. Santiago: Instituto Profesional Blas Cañas.
Vázquez de Acuña, I. (1977-1978). El descubrimiento y conquista de Chiloé. Boletín de la Academia Chilena de la Historia, 90, 129-163.

Vázquez de Acuña, I. (1993). La jurisdicción de Chiloé (siglos XVI al XX). Su extensión, exploración y dominio. Boletín de la Academia Chilena de la Historia, 103, 111-191.

Vázquez de Acuña, I. (2003). La incursión del Comodoro George Anson (1740-1744) y sus consecuencias en Chile. Boletín de la Academia Chilena de la Historia, 112, 215-247.

Vázquez de Acuña, I. (2004). Historia naval del Reino de Chile. Valparaíso: Compañía Sudamericana de Vapores.

Vea, A. [1676] (1886). Relación diaria que se ha hecho a las costas del estrecho de Magallanes con recelo de enemigos de Europa por don Antonio de Vea (1675-1676). Anuario Hidrográfico de la Marina de Chile, 9, 525-537.

Vidts, E. (1921). Ventajas de la apertura del istmo de Ofqui. Revista Chilena de Historia y Geografía, 42, 139-143.

Vivar, G. [1558] (1979). Crónica y relación copiosa y verdadera de los Reinos de Chile. Edición de Leopoldo Sáez Godoy. Berlin: Biblioteca Ibero-Americana, Colloquium Verlag.

Walter, R. (1748). A voyage round the world, in the years MDCCXL, I, II, III, IV, by George Anson, esq., commander in chief of a squadron of His Majesty's ships, sent upon an expedition to the South-Seas/compiled from papers and others materials of the Right Honourable George Lord Anson, and published under the direction by Richard Walter. Londres: Printed for the author, by John and Paul Knapton.

Weber, D. (2007). Bárbaros. Los españoles y sus salvajes en la era de la Ilustración. Madrid: Editorial Crítica.

Williams, G. (2002). El mejor botín de todos los océanos. La captura de la nao de China en el siglo XVIII. México: Editorial Océano.

Urbina, M.X. (2010). La navegación por los canales australes en la Patagonia occidental insular en los siglos coloniales: la ruta del istmo de Ofqui. Magallania, 38(2), 41-67.

Urbina, M.X. (2013a). Traslados de indígenas de la Patagonia occidental insular a Chiloé en los siglos XVI, XVII y XVIII. En Valenzuela, J. (ed.). América en diásporas: esclavitudes y migraciones forzadas (siglos XVI-XIX). Santiago: Instituto de Historia, Pontificia Universidad Católica de Chile/RiL editores (en proceso editorial).

Urbina, M.X. 2013b. Expediciones desde Chiloé para recoger el metal del barco inglés Wager de la flota de George Anson, naufragado en el Pacífico austral en 1741: el conflicto del hierro en Chiloé. Manuscrito inédito.

Urbina, M.X. y Chapanoff, M. (2010. El protagonismo de la dalca en las navegaciones australes coloniales. Actas de las Jornadas de Historia Naval y Marítima de 
Chile, 5, 63-72.

Vázquez de Acuña, I. (1977-1978). El descubrimiento y conquista de Chiloé. Boletín de la Academia Chilena de la Historia, 90, 129-163.

Vázquez de Acuña, I. (1993). La jurisdicción de Chiloé (siglos XVI al XX). Su extensión, exploración y dominio. Boletín de la Academia Chilena de la Historia, 103, 111-191.

Vázquez de Acuña, I. (2003). La incursión del Comodoro George Anson (1740-1744) y sus consecuencias en Chile. Boletín de la Academia Chilena de la Historia, 112, 215-247.

Vázquez de Acuña, I. (2004). Historia naval del Reino de Chile. Valparaíso: Compañía Sudamericana de Vapores.

Vásquez de Espinoza, A. [1619] (1986). Descripción del reino de Chile. Santiago: Instituto Profesional Blas Cañas.

Vea, A. [1676] (1886). Relación diaria que se ha hecho a las costas del estrecho de Magallanes con recelo de enemigos de Europa por don Antonio de Vea (1675-1676). Anuario Hidrográfico de la Marina de Chile, 9, 525-537.
Vidts, E. (1921). Ventajas de la apertura del istmo de Ofqui. Revista Chilena de Historia y Geografía, 42, 139-143.

Vivar, G. [1558] (1979). Crónica y relación copiosa y verdadera de los Reinos de Chile. Edición de Leopoldo Sáez Godoy. Berlin: Bibliotheca Ibero-Americana, Colloquium Verlag. Walter, R. (1748). A voyage round the world, in the years MDCCXL, I, II, III, IV, by George Anson, esq., commander in chief of a squadron of His Majesty's ships, sent upon an expedition to the South-Seas / compiled from papers and others materials of the Right Honourable George Lord Anson, and published under the direction by Richard Walter. Londres: Printed for the author, by John and Paul Knapton.

Williams, G. (2002). El mejor botín de todos los océanos. La captura de la nao de China en el siglo XVIII. México: Editorial Océano.

Weber, D. (2007). Bárbaros. Los españoles y sus salvajes en la era de la Ilustración. Madrid: Editorial Crítica. 
M. XIMENA URBINA 